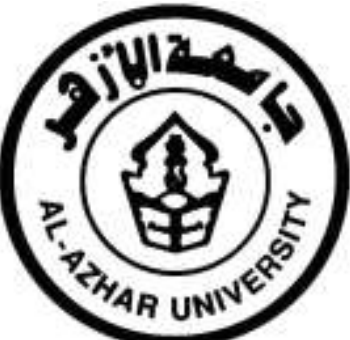

$$
\begin{aligned}
& \text { جامعست الأزهــــر } \\
& \text { كليـت أصسـول الاديـن } \\
& \text { واللدعوة الإسلاميت بالمنوفيتن }
\end{aligned}
$$

$$
\begin{aligned}
& \text { الأخر الدهوي } \\
& \text { مفهومهه - أقسامه - طرق قياسه }
\end{aligned}
$$

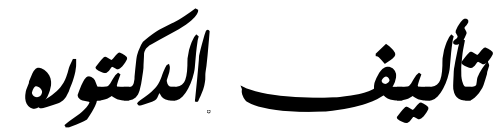

\title{
فاطمة بنت سعود الكميلي
}

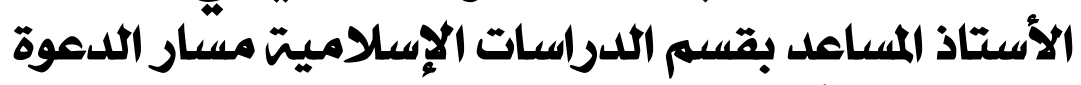

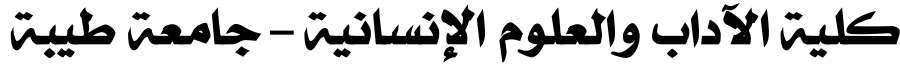

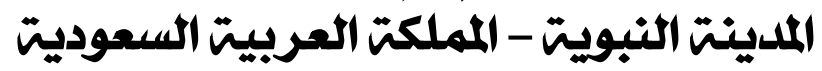

\author{
as äliwo
}

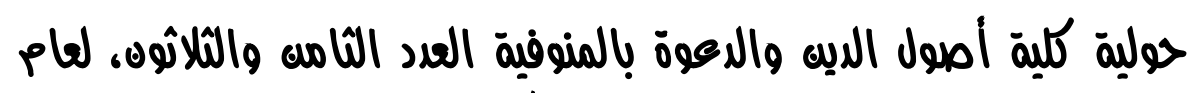

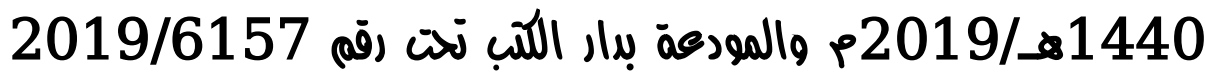
والترقيه الدوله

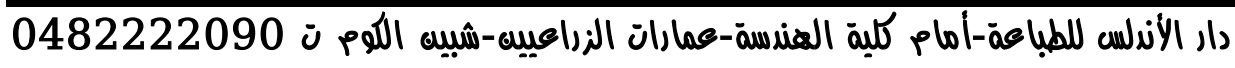




\section{حولية كلية اصول الدين والدعرة بالثنوفية العدد الثامن والثلاثثون}

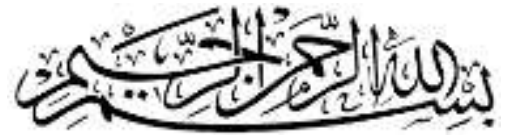

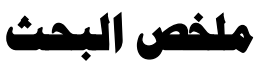

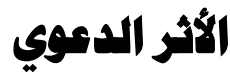 \\ مفهومهـ - أقساميه - طرق قياسه}

الحمـد لله رب العـالمين، والصــلاة والسـلام على سـيد المرسـلين سيدنا و نبينـا

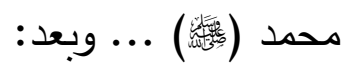

ويتكون هذا البحث "الأثر الدعوي، مفهومسه وأقسامه وطرق قياسـه" من مقدمـة

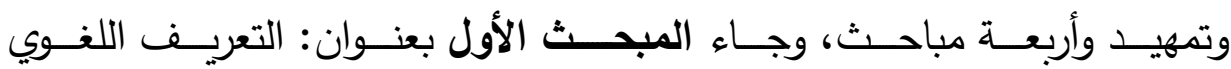
والاصـطلاحي لمفـردة الأثر ، ويتكون مـن مطلبين، ثم ختم المبحـث بـالتعريف الإجرائي لمصطلح الأثر الدعوي وهو: مخرجات العمل الدعوي وثمرته ونتائجه، الحسية والمعنويـة، والإيجابيـة والسـلبية، والتي تدل على مسـتوى الـدعوة المقدمـة

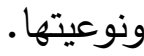

وجاء المبحث الثاني بعنوان: معاني الأثر في القرآن الكريم والسنة النبويـة، وذلك في مطلبين، الأول للقـرآن الكريم والثاني لمعنى الأثر في السـنة النبويـة الشريفة. أمـاَّ المبحث الثالث فكان في أقسـام الأثر الدعوي الخمسـة والمرتبطة بأركان الدعوة الأساسية وهو الداعية والمدعو، ووسائل الدعوة وأساليبها، وموضدوع الدعوة ونهجها.

والمبحث الرابع بعنوان طرق قياس الأثر الدعوي ويتكون من مطلبين، أولهما توطئة مهمة:في بيان المراد من الأثر الدعوي ثم المطلب الثاني: ذكر طرق قياس الأثر الدعوي وهي ثلاثة: أولهما استخدام أدوات القياس المعروفة من استبانات، 
ومقابلات، وملاحظـات، ومؤشرات كميـة ونوعيـة، ومختبرات ومعاملـ، وتجـارب، مهـا يُستخدم في العلوم الأخرى، وثانيهمـا القياس مـن خـلال النصـوص الثـرعية

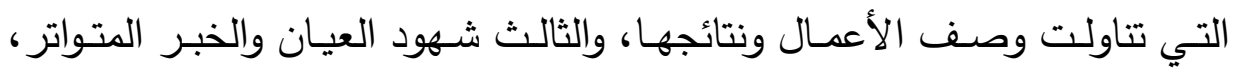
وجاء بعد ذلك ملحق بالدراسات والبحوث العلمية التي درست الأثر الدعوي، وفي الختـام جـاءت نتـائج البحـث وتوصـياته، وفهـرس المصــادر والمراجـع وفهـرس

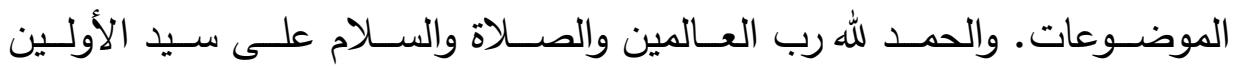
والآخرين (筷) وعلى آله وصحبه أجمعين. الكلمات الافتتاحية: الأثر الاعوي - المفهوم - الأقسام - طرق القياس

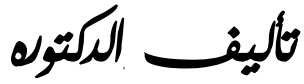

\section{فاطمة بندت سمعود الكميلي

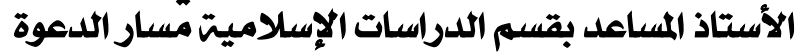

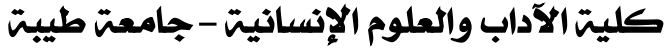 \\ المدينت النبويت - المملكت العربيت السعوديت المعتيت}

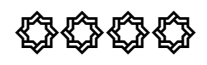




\section{Search Summary \\ Da'wa Effect Understandable Methods of Measurement Sections}

Praise be to Allah, the Lord of the Worlds, and prayers and peace be upon the master of the Messengers our Prophet Muhammad (peace and blessings of Allaah be upon him). And after:

The research consists of "the action, the concept, its sections and the methods of measuring it" from an introduction, a preface, and four detectives, the first of which is titled: The Linguistic and terminological definition of the single effect, consisting of two demands, and then the conclusion of the discourse with the procedural definition of the term effect: the outcomes of the work and the outcome Sensory, moral, positive and negative, which indicate the level and quality of the call made.

The second topic titled: Meanings of Impact in the Holy Qur'an and Sunnah, in two demands, the first of the Holy Qur'an and the second meaning of impact in the year.

The third section was in the impact sections of the five proceedings, which are linked to the basic elements of advocacy, the Advocate and invited, the means and methods of advocacy, and the subject and approach of advocacy

The fourth topic is the methods of measuring the impact of the action and consists of two demands, the first of which is important in the statement of the intended effect of the action and then the second requirement mentioned methods of measuring the impact of the action: the first is the use of known measurement tools of questionnaires, interviews, observations, quantitative and qualitative indicators, laboratories and laboratories, experiments, which are used in other sciences, and the second measurement through the Shariah texts that dealt with the description of the works and their results, and the third eyewitnesses and frequent news, and then came attached to the scientific studies and researches that examined the effect of the action, and in conclusion came the results of the research and its recommendations, And index of sources, references and index of subjects. Praise be to Allah, the Lord of the Worlds, and prayers and peace be upon the master of the first two and the others (peace be upon him).

Key Words: Da'wa Effect - Understandable - Methods - Mwasurement Sections

\section{Dr. Fatima Bint Saud A[- Kohili \\ Assistant Profeesor of Islamic Studies Call \\ Path, Faculty of Arts and Humanities, University of Taiba alkehale@gmail.com}

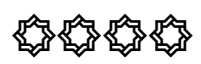




\section{(v)}

إن الحمد الله نحمده ونستعين بـه، ونعوذ بـاله من شرور أنفسنا ومن سيئات أعمالنا، من يهده الله فلا مضل له، ومن يضلل فلا هادي لله، وأثهر أن لا إله إلا لا

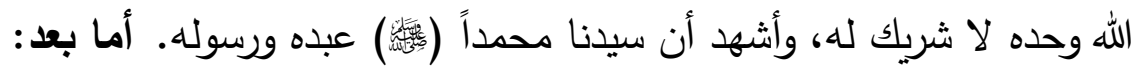

\section{أهمبة موضو ع البهث:}

قضـى الله تبـارك وتعـالى أنَّ ينتشـر الإسـلام بقيـام المسـلمين بالـــعوة إليـه، وكلفّهم بذلك، وجعل خيريـة الأمـة المسلمة مرتبطة بالدعوة إلى الله تعالى، والقيام

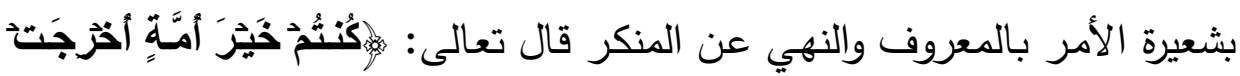

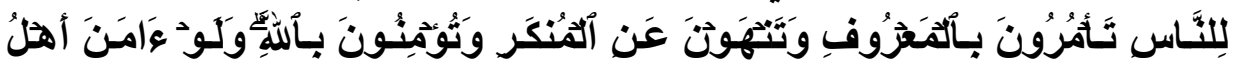

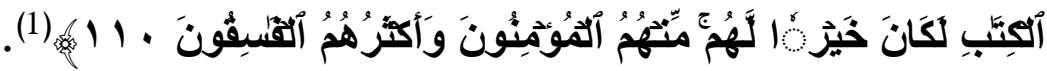
وكل مـا يصدر عن الإنسان من قول وفعل يكون لـه أثر، وقد كانت آثار

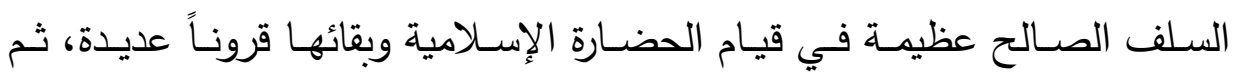
ضَعُف المسلمون، وقلَّ جهدهم في الدعوة إلى الله تعالى حتى ظهرت آثار ذلك الضعف في تأخر الأمة الإسلامية عن الدور القيادي الذي خُلقت لله، وهي مهيأة لتكون كذلك بسبب الدّين الإسلامي الذي تؤمن به. وتظهر أهمية موضوع "الأثر الدعوي" في أنه مؤشر قوي على حالة المسلمين لهين

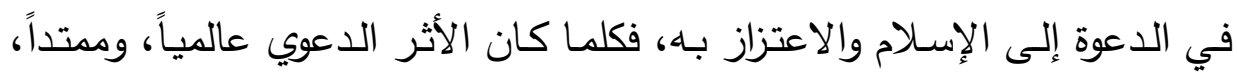

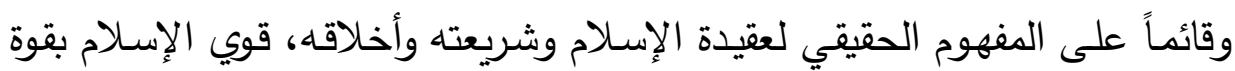
دعاته، والعكس صــيح، فهـي علاقـة طرديـة، بـين الأثر الـدعوي وبـين قيـام المسلمين بواجب الدعوة إلى الإسلام. 
أسباب افتنبار موضوع البهث:

من الأسباب التي دفعتنى للكتابة في هذا الموضوع، ما يلي:

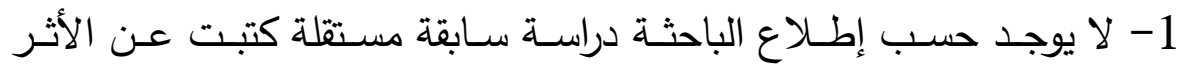
الدعوي كمصطلح دعوي لـه تعريف يختص بـه، ويوجد كثير جدا من البحوث والدراسات العلمية المتخصصة بالدعوة التي بينت الأثر الدعوي في قضـايا دعويـة مختلفة، دون التطرق لتعريف الأثر الدعوي كمصطلح. 2- لم تجد الباحثة دراسة تطرقت إلى كيفية قياس الأثر الدعوي وبيان طرق القياس وأنواعها. 3- أنَّ الأثر ورد ذكره في واحدٍ وعشـرين موضـعاً في القرآن الكريم، وفي الحديث الثريف تكرر ذكر الأثر ومشتقاته من الألفاظ كثيراً، وبيان ذلك وتقرير

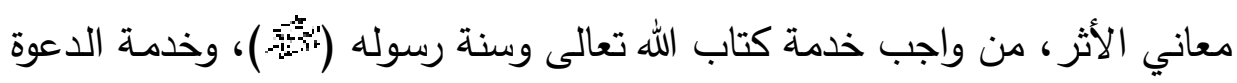
إلى الله تعالى. 4- الحاجة المَّاسة للتعامل مـع قضـايا الدعوة وما يرتبط بها ويؤثر فيها، إلى لى دراسـات ميدانية تُقدم إحصـاءات وإرقامـاً عن آثار الدعوة إلى الله، حتى يتم تقييم واقع الدعوة تقييما علمياً منهجياً وليس تقييماً قائماً على الرؤية العامة والتخمين. أهداف موضوع البهنذ:

1- تقرير تعريف لُغوي واصطلاحي خاص "بالأثر الدعوي" كمصطلح دعوي. 2- بيان معاني الأثر في القرآن الكريم والسنة النبوية المطهرة. 3- ذكر أقسام الأثر الدعوي المتعلقة بالداعية والمدعو، ووسائل الدعوة وأساليبها، وموضوع الاعوة ومنهجها. 4- وضع طرق لقياس الأثر الدعوي، وبيان أهميتها وأسلوب تتفيذها. 


\section{مناهيج البهث:}

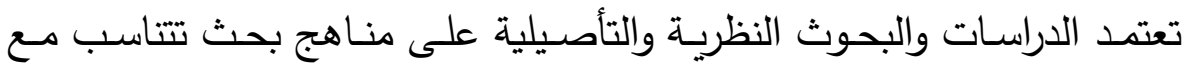

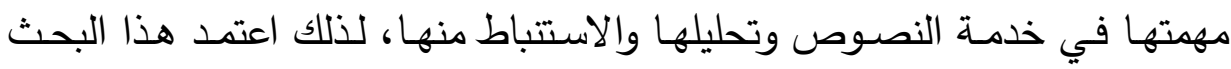
على المنهج الاستقرائي (1) في جمع المعلومات والبيانات المتعلقة بموضوع البحث

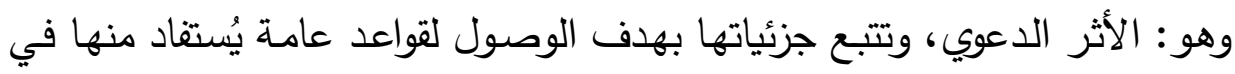
علم الدعوة إلى الله تعالى.

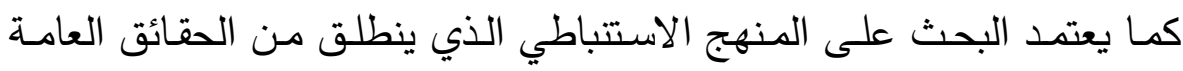

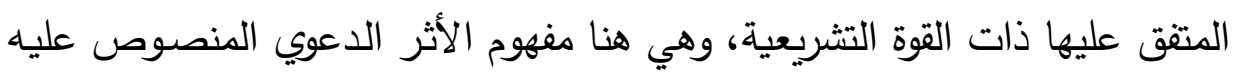

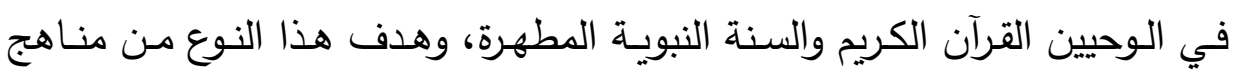

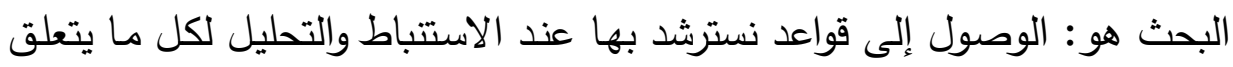
بالأثر الدعوي إلى الله تعالى من إيجابيات أو سلبيات(2).

\section{الدراسات السابقة:}

لم تجد الباحثة فيما وققت عليه دراسة مستقلة تناولت الأثر الدعوي وأنواعـه وطرق قياسه، رغم وجود دراسات علمية لأطروحات دكتوراه وماجستير كثيرة جداً

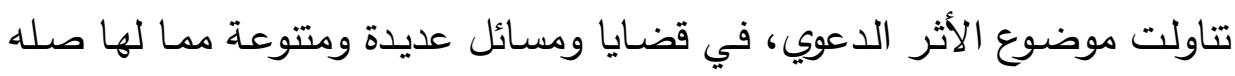

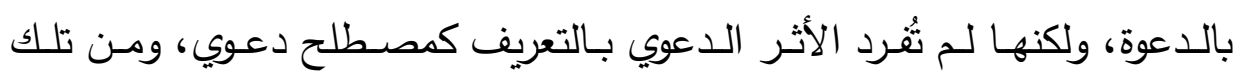

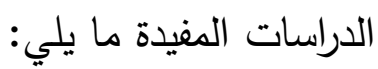

(1) انظر : قواعد أساسية في البحث العلمي، د. سعيد الصيني، ص73، طا11، 1415هـ،

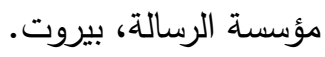

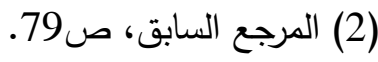


1- رسالة دكتوراه بعنوان "أثر الوقف على الدعوة إلى الله تعالى"(1).

2- رسالة دكتوراه بعنوان "موقف الإسلام من العقل وأثره في الدعوة"(2).

3- رسالة ماجستير بعنوان "الرفق وأثره في الدعوة إلى الله تعالى"(3).

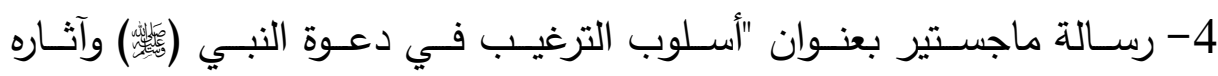

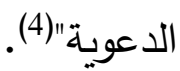

5- رسالة ماجستير بعنوان" الموعظة الحسنة للعلماء وأثرها في الدعوة إلى الله

تعالى ") (5) (5). (5)

وكما سبق بيانه فالدراسات كثيرة جدا، وهي مفيدة في التأصيل للأثر الدعوي

$$
\text { في موضوعات الدعوة. }
$$

مخطh الب منث:

يتكون البحث من مقدمة وتمهيد وأربعة مباحث وملحق الدراسة والخاتمـة وقائمة المراجع والفهرس العام وهي كالتالي:

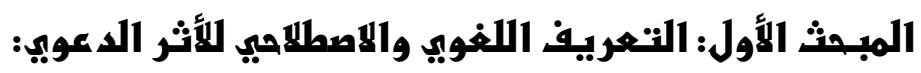
المطلب الأول: التعريف اللغوي لمفردة "الأثر"

(1) خالد المهيدب، ط1، 1426هـ، وزارة الثئون الإسلامية والأوقاف، الرياض.

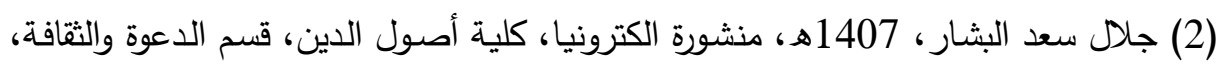
القاهرة.

(3) نورة عبد اللطيف فرج، ط1، 1430هـ، الناشر : جامعة أم القرى، مكة المكرمة.

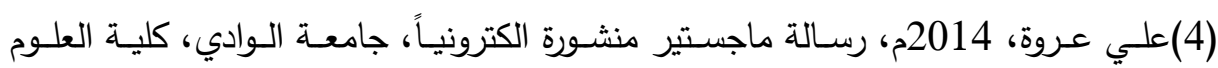
الاجتماعية والإنسانية، قسم العلوم الإسلامية، الجزائر .

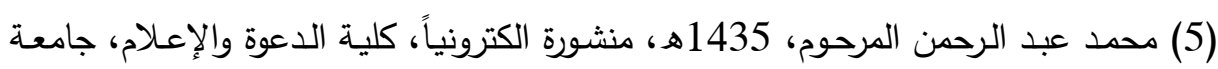
الإمام محمد بن سعود الإسلامية، الرياض. 
المطلب الثاني: التعريف الاصطلاحي لمفردة " الأثر"

المطلب الثالث: التعريف الاصطلاحي للأثر الدعوي وشرح التعريف.

المبــث الثناني: معانبي الأنثر في القرآن الكربم والهديث الشريذ:

المطلب الأول: معاني الأثر في القرآن الكريم.

المطلب الثاني: معاني الأثر في الحديث الثريف.

المبـهث الفالث: أقتسام الأنثر الد عوي:

1 - الأثر الدعوي على الدعاة.

2- الأثر الدعوي على المدعوين.

3- الأثر الدعوي على موضوع الدعوة.

4- الأثر الدعوي على وسائل الدعوة وأساليبها.

5- الأثر الدعوي على منهج الدعوة.

المبــث الرابـر: طرق قباسر الأنثر الدعوي.

المطلب الأول: توطئة في قياس الأثر الدعوي.

المطلب الثاني: طرق قياس الأثر الدعوي.

فاتهة البهث وفيها:

نتائج البحث.

توصيات البحث.

فهرس المصادر والمراجع.

فهرس موضوعات البحث.

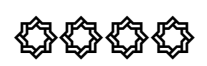




\section{المبمث الأول}

\section{التعريف اللغوي والاصطلاجي اللأثر الدعوي}

توطأة:

تستخدم بكثرة مفردة "أثر" في الرسائل العلمية الماجستير والدكتوراه، والأبحاث العلمية، وفي كل التخصصـات التطبيقية منها والنظريـة، وذلك لأهمية الأثر في بيان حالة موضـوع البحث ونتائجها، ومـا يقدمـه من بيانـات تسـاعد على التطوير والتحسين، كما أنها تبين مواطن الضعف والقصور .

\section{المطلب الأول}

\section{التعريف اللغوي المغردة "ألثر"}

للأثر في اللغة عدة معانٍ ومنها:

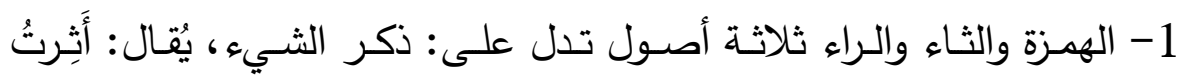

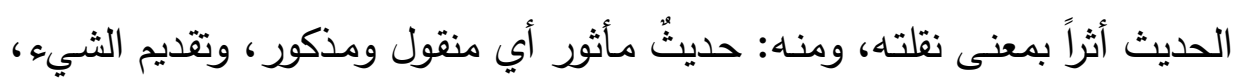

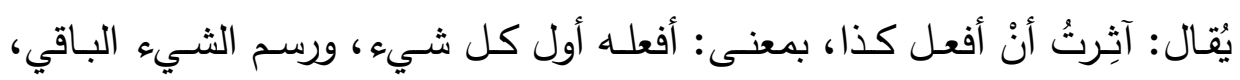

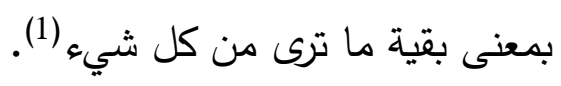

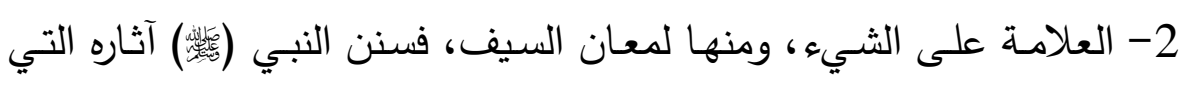
تدل عليه (2).

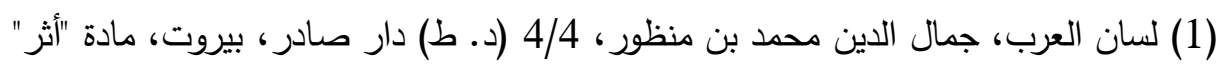

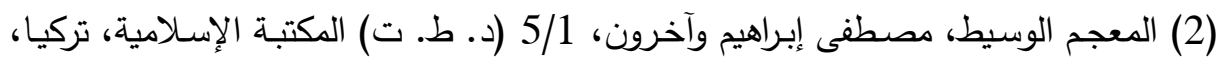

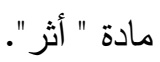


3- ما خلَّفه السابقون، ومنها الخبر المروي (1).

4- الأثر بمعنى النتيجة، وهو الحاصل من الثيء (2).

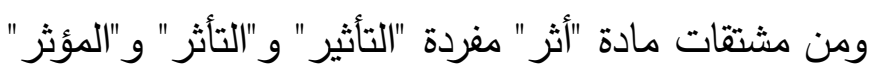

والنأثير معناه:

إبقاء الأثر في الثـيء، وأثنَّر في الثـيء أي ترك فيـه أثراً، فأثرت فيـه تأثيراً معناها: جعلت فيه أثراً وعلامهة، فتأثر فلان أي قَبِلَ وانفعل، ومحل التأثرير يكون في السلوك، إماًّ الإتيان أو الترك(3).

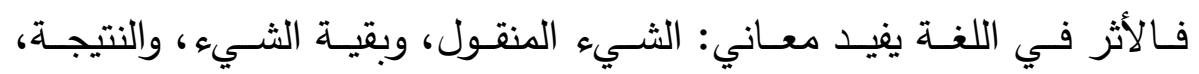

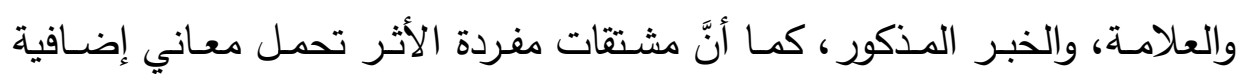
أخرى غير تلك التي تحملها مفردة الأثر لوحدها، وهذا مـن دلالات قوة اللغــة العربية، وسعة مشتقاتها واستيعابها للمعاني الكثيرة.

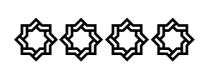

(1) المعجم الوسيط، مصطفى إبراهيم وآخرون، 5/2 (د. ط. ت) المكتبة الإسـلامية، تركيا،

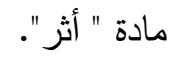
(2) التعريفـات، الجرجـاني، تحقيـق: إبـراهيم الأبيـاري، صاد30، ط2، 1423هـ، دار الكتـاب العربي، بيروت.

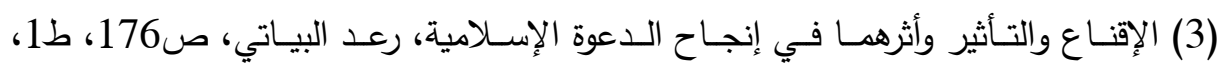

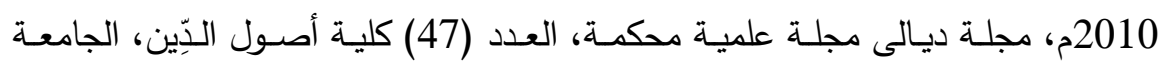
الإسلامية، بغداد. 


\section{الإلب الثاني \\ التعريف الاصطلاجي الثردة " أثرل}

الأثر في الاصطلاح العام هو: "حصول ما يدل على وجوده"(1). الأثر عند المهدثيز:

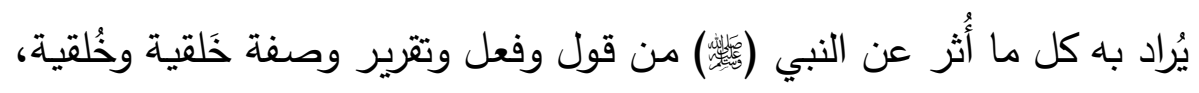

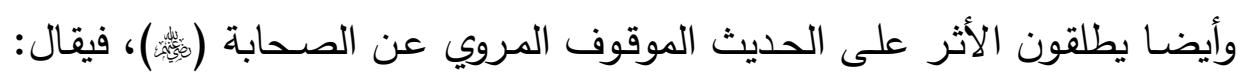

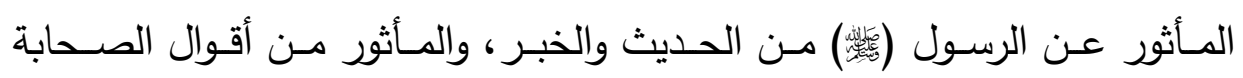
(2)(䜌)

\section{الأثر عند الفقهاء والأصوليين:}

الفقهاء وعلماء الأصول مثل الدحثين يستخدمون الأثر بمعنى الحديث المروي

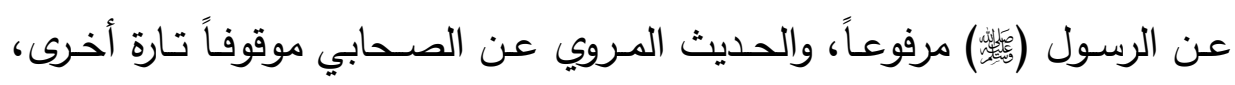
ويستخدم الفقهاء الأثر مضافاً فيقولون: أثر العقد، وأثر الفنخ، وأثر النكاح، وأثر الثرائ البيع(3).

\section{الأثر الد عوي:}

إنَّ المحدثين والفقهاء والأصوليين وضعوا تعريفاً للأثر يتناسب مع معانيه في

(1) الدفردات في غريب القرآن، الراغب الأصفهاني، تحقيق: محمد كيلاني، ص99، ط1

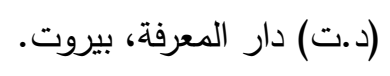

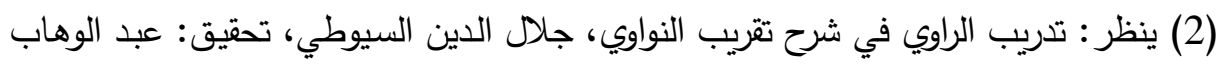

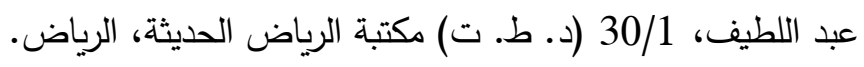

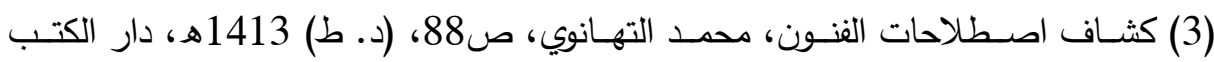

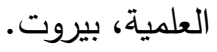


اللغة، ثم أضافوا عليه أوصافاً تتفق مع مجال تخصصهم، وحريٌّ بأهل الدعوة أن

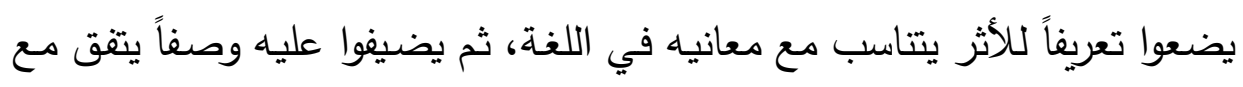
تخصصهم.

وقد سبق ذكر أنَّ مفردة " الأثر" تستخدم بكثرة في الأبحاث العلمية والتي منها

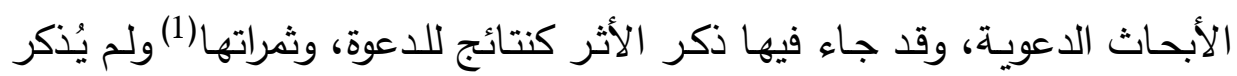

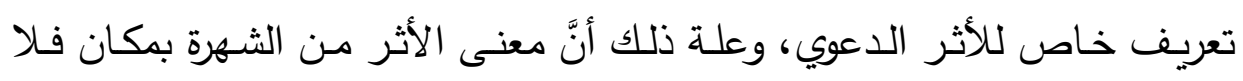

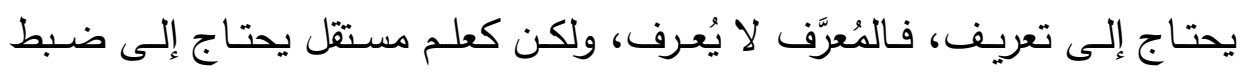

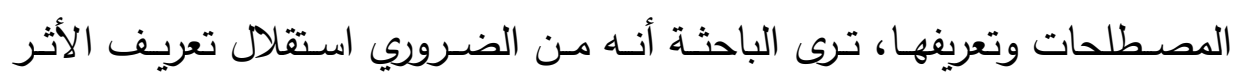
الدعوي بتعريف خاص به.

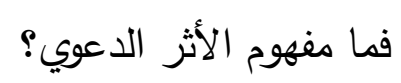

\section{المطلب الثالث}

\section{التعريف الاصطلاحي للأثثر الدعوي وثشرح التعريف}

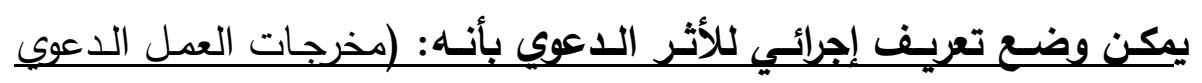

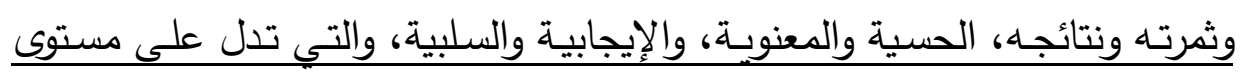

الدعوة المقدمة ونوعيتها)(2).

شرح التعربف الاصطلاحي للأثر الدعوي (3):

(1) - (1) ينظر : الملحق.

(2) تعريف الباحثة.

(3) تؤمن الباحثة أنَّ الدعوة إلى الله تعالى نظام متكامل يدل على كمال الإسـلام وشموله، كما

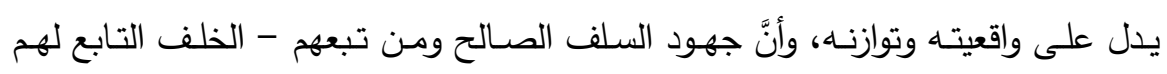

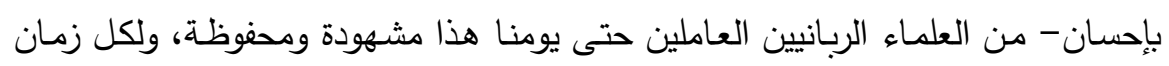
لغته وأسلوبه، ومما تحتاجه الدعوة اليوم هو تدوين وكتابة هذا النظام الدعوي الرباني في لئين 


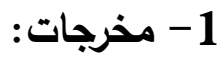

أصل كلمة مخرجات الفعل "خرج" ومن مشتقاته مفردة" مخرجات" وتعني أنَّ

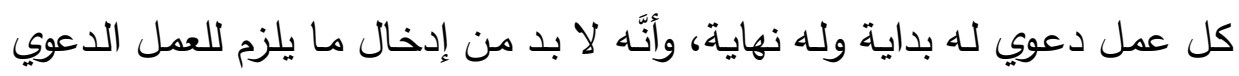

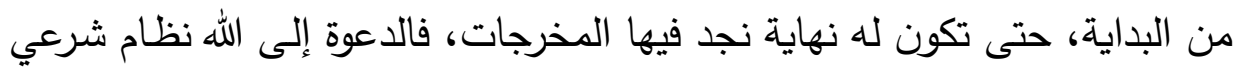

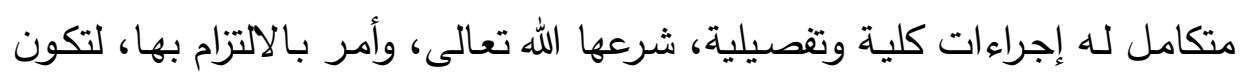

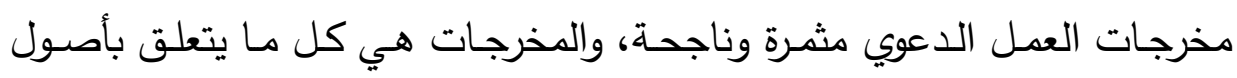

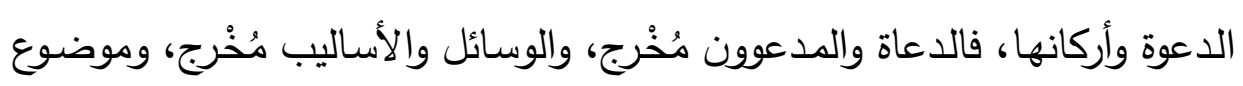

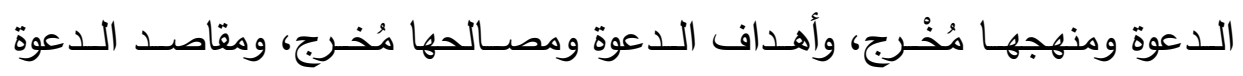

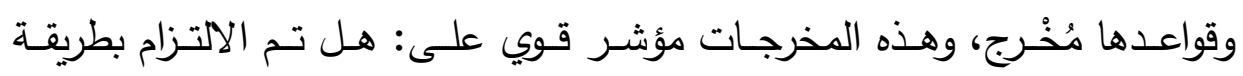

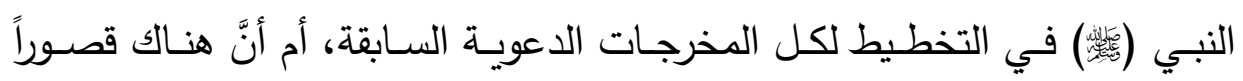

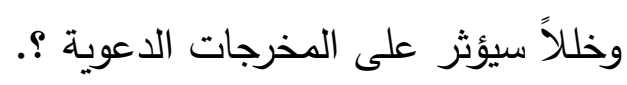
2- 20 - 20 - العمل الدعوي:

المراد كل عمل مقصود به الدعوة إلى الله تعالى وإلى الدّين الإسلامي، ويدخل

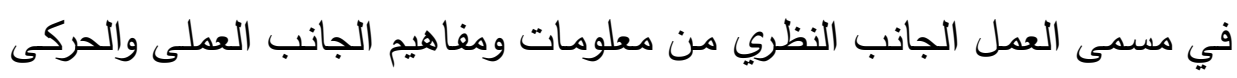
بما فيه من برامج وخطط. وتُعرّف الدعوة إلى الله بأنها: "تبليخ الناس جميعاً دعوة الإسلام، وهدايتهم إليها

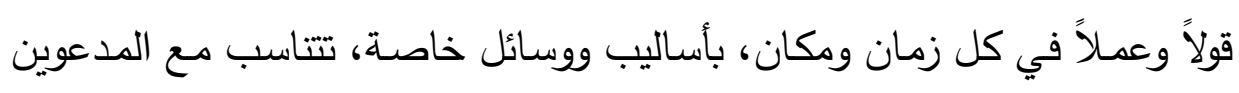
على مختلف أصنافهم وعصورهم" (1).

$=$

وموثق، ودليل يسترشد به الدعاة والمؤسسات الدعوية وكل ما له صلة بلدي بالدعوة.

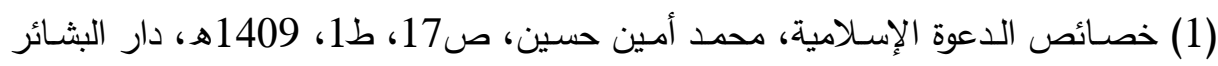

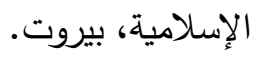


المقصود بها الحسنات والإيجابيات المستفادة للدعوة، ويغلب على ثـرات أي عمـل أنَّ المـراد بهـا هـو الخيـر، وينـدر ويقـل اسـتخدام لفظظ ثـرة في السـيئات والسلبيات، ولذلك تم ذكرها لوحدها في التعريف.

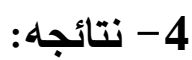
مــا دام أنَّ الــدعوة عمـل، فلكـل عمـل نتـائج وهـي تثـمل الحســـة والسـيئة، والإيجابي والسلبي، والمقبول والمرفوض، والثرعي وغير الشرعى والمباح والمحرم،

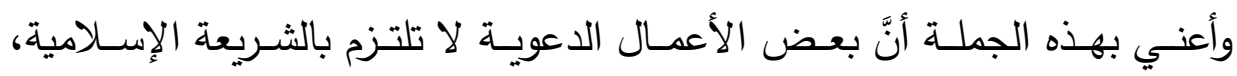

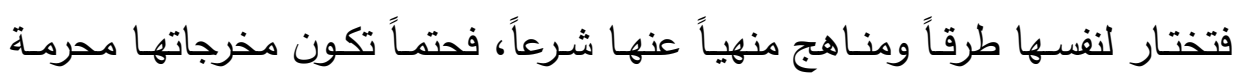

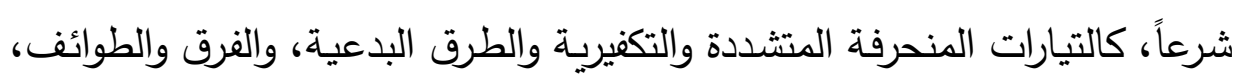
والجماعات الإرهابية.

$$
\text { 5 }
$$

أي الأمور المادية المحسوسة مثل: الإنفاق المالي للدعوة والتبرعات، الأوقاف الدعوية من مساكن ومزارع، المؤسسات والشركات، المؤلفات والمطبوعات، وغيرها كثير من الأمور المحسوسة والتي تم تخصيصها للدعوة إلى الله. 6

مقابل الأمسور المادية مثل: القيم والأخـاق، فإذا ارتقت قيم المجتمع وأخلاقهـ بفعل الـدعوة إلى الله فهذا مخرج معنـوي للدعوة وليس حسياً، لارتباطـه بـالفكر والقلب والسلوك، الإقبال على داعية من الدعاة والتأثر به دون غيره، فهذا مُخْرج

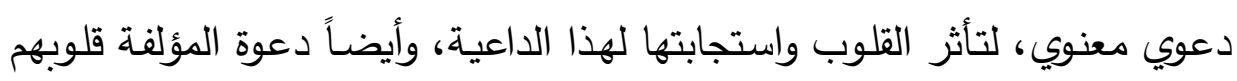
ممن لم يُسلم، أو أسلم على ضعفِ في إسلامه وغيرها كثير . دمع 
7- الإيجابية السلبية:

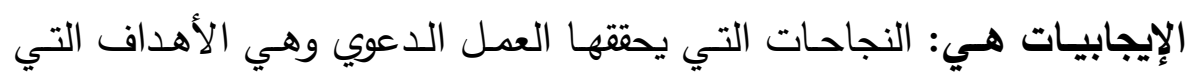

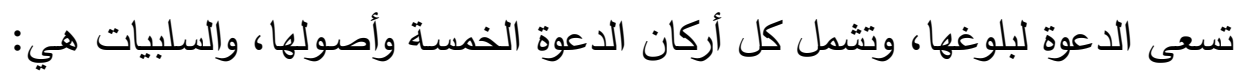

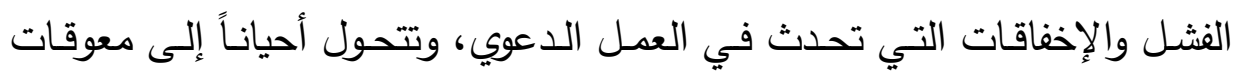

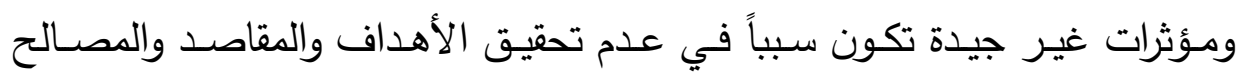

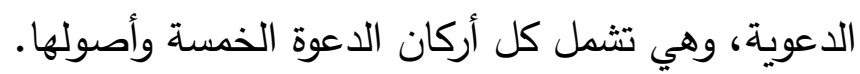

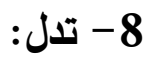

هذه الكلمة المكونـة من ثلاثة أحرف، هي عالية الأهميـة، وضـرورية للغايـة

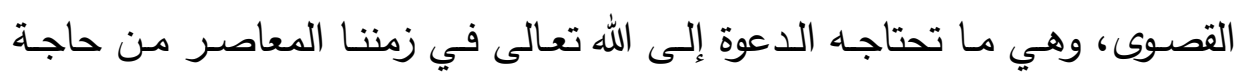

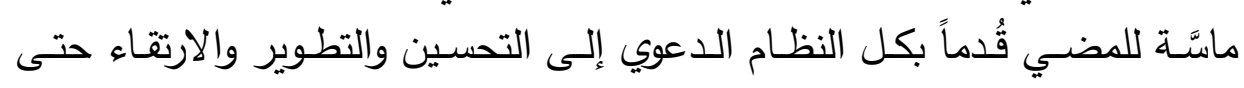

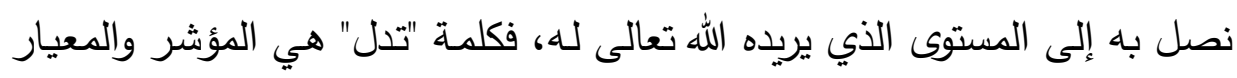

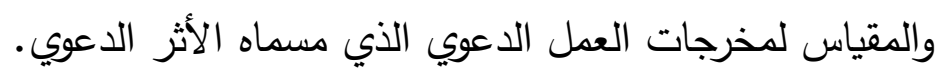

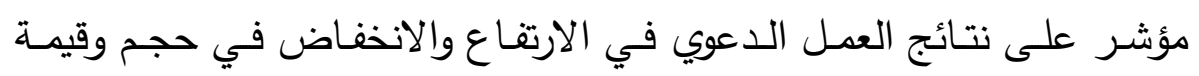

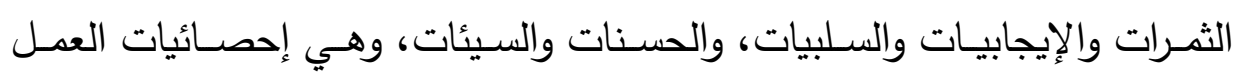

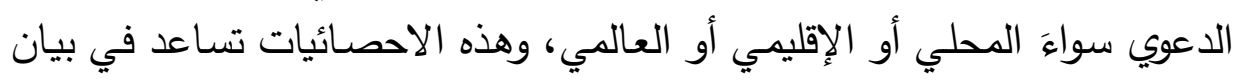

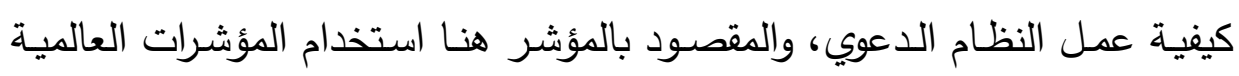

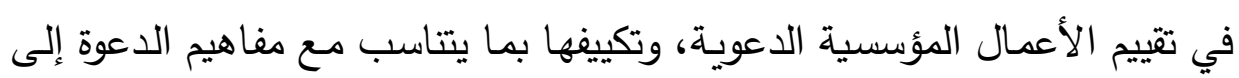

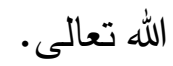

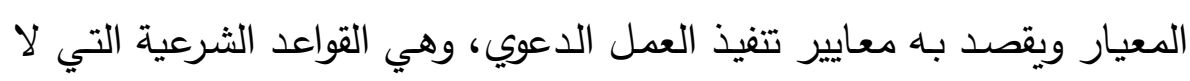

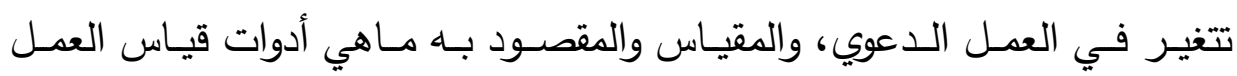

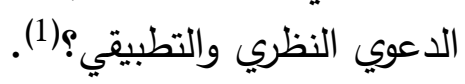

(1) للاستزادة يُنظر : مركز أصول العالمي للمحتوى الدعوي.

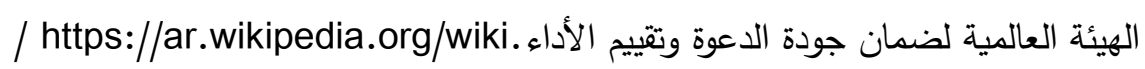

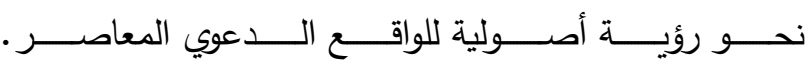


9- مستوى الدعوة المقدمة:

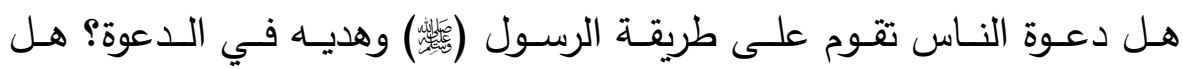

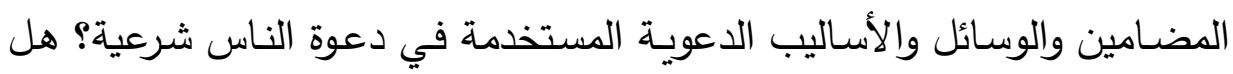

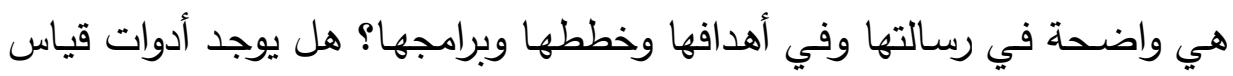

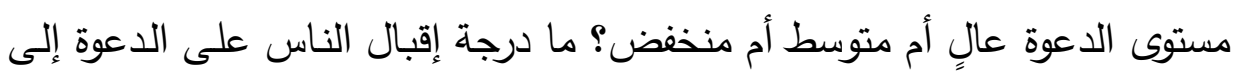

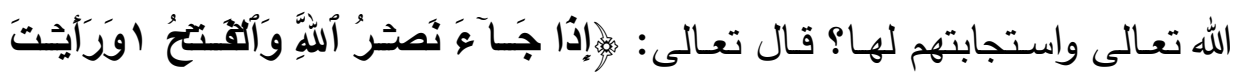

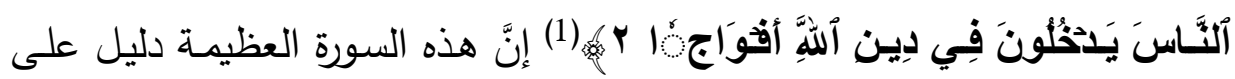

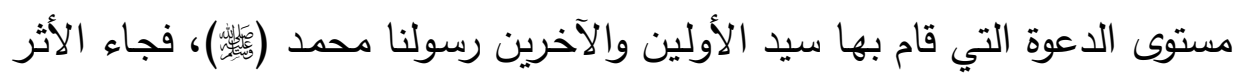

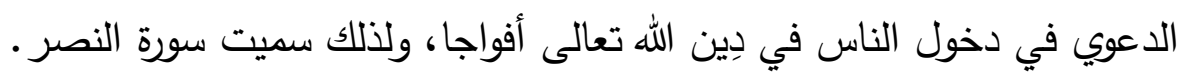
10 - نوعيتها: والمراد بالنوع هنا هل الدعوة إلى الله على منهج أهل السنة والجماعة أم أنها

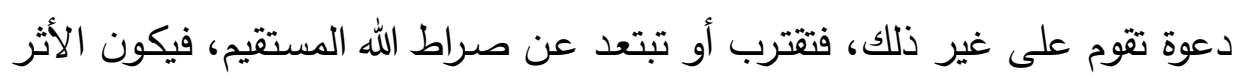

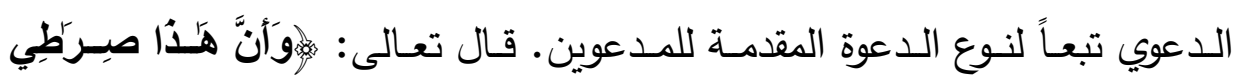

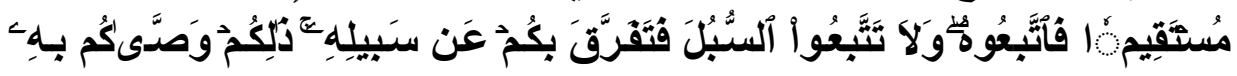

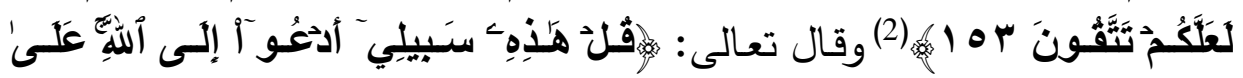

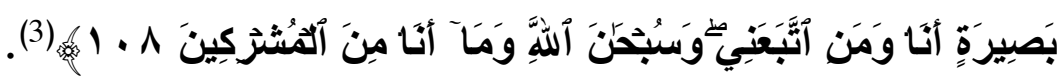

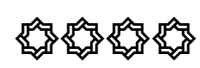

=https://www.alukah.net/sharia/0/5830 


\section{الإبمث الثاني}

\section{معاني الأثثر في القرآذ الكريم والمديث الششريف.}

\section{الإطلب الأول \\ معنى الأثر في القرآن الكريم}

ورد لفظ الأثر في القرآن الكريم والحديث الثريف، كما جاءت معانيه مطابقة للمعني اللغوي كما هو في لغة العرب، وفيما يلي جدول يبين الآيات الكريمة التي ورد فيها لفظ الأثر ومشتقاته اللغوية مع بيان المعنى المراد منها.

\begin{tabular}{|c|c|c|}
\hline معنــ الأنثر فيها & آلآية الكربيهة & م \\
\hline 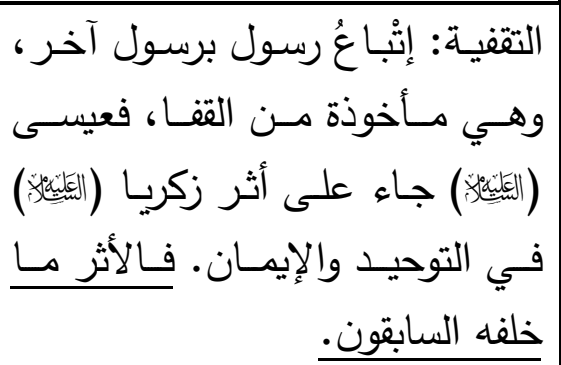 & 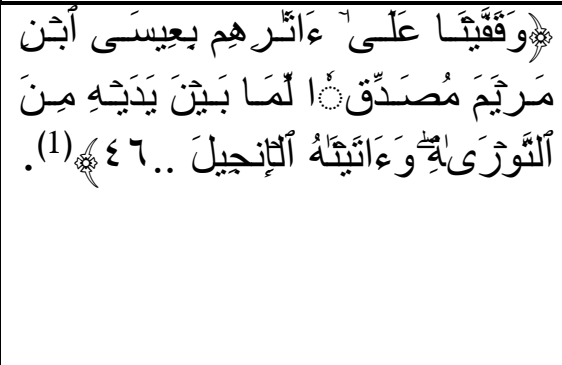 & 1 \\
\hline 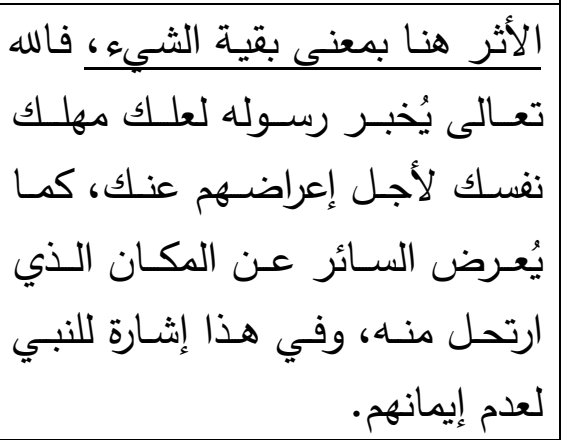 & 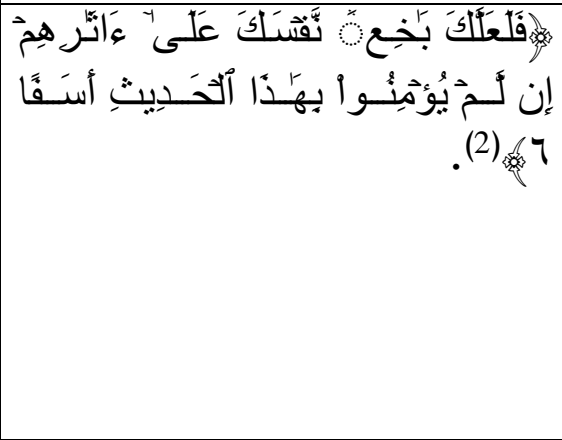 & 2 \\
\hline آثار الأعمـال وليس عين الأعمـال & 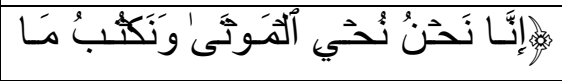 & 3 \\
\hline
\end{tabular}

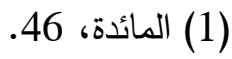

(2) الكهف، 6. 


\begin{tabular}{|c|c|c|}
\hline 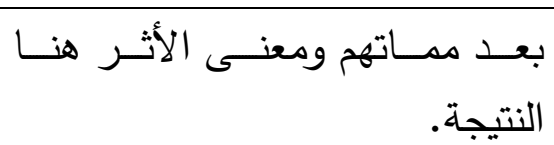 & 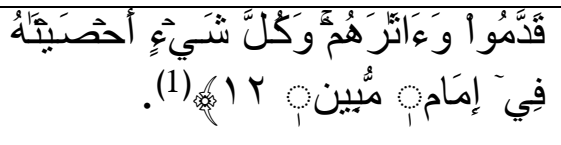 & \\
\hline 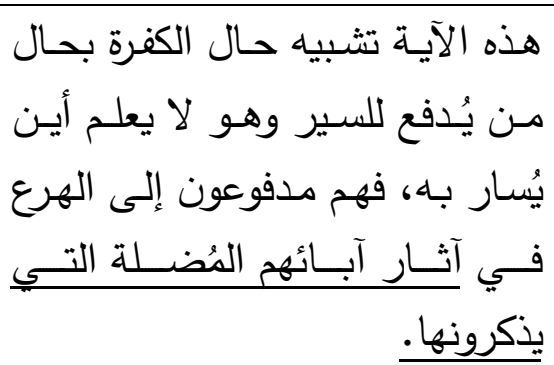 & 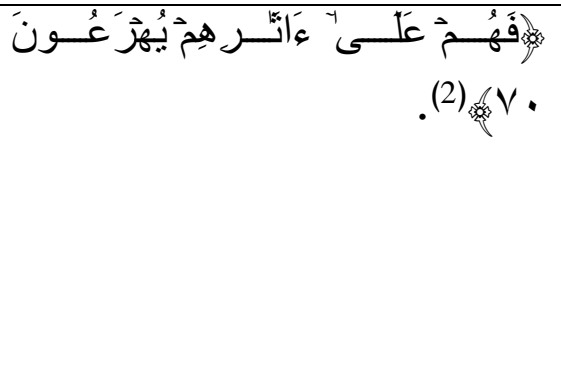 & 4 \\
\hline هذهـ الآيـة مثل السـابقة معنــ الأثر & 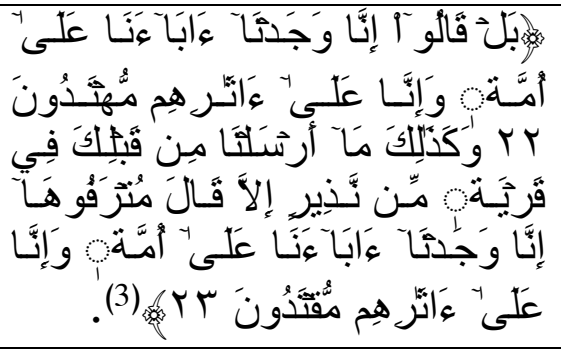 & 5 \\
\hline 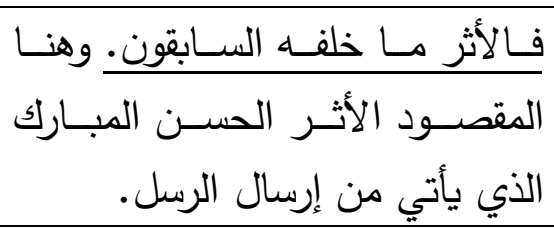 & 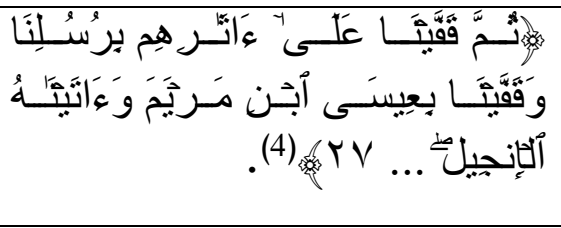 & 6 \\
\hline نقول الأثر هنـا بمعنى التعليم، فالسـامري & 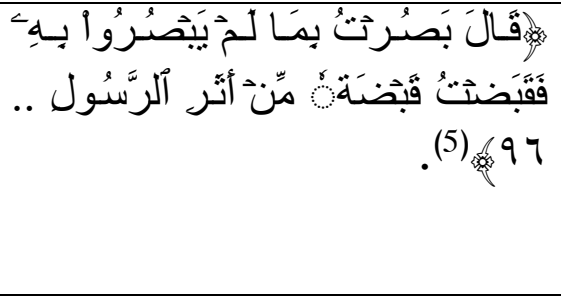 & 7 \\
\hline
\end{tabular}

$$
\begin{aligned}
& \text { (1) يس، } 12 . \\
& \text { (2) الصافات، } 70 \text { (1) لبر، } \\
& \text { (3) الزخرف، 22-23. } \\
& \text { (4) الحديد، الرحر، } 27 . \\
& \text { (5) طه، } 96 .
\end{aligned}
$$




\begin{tabular}{|c|c|c|}
\hline 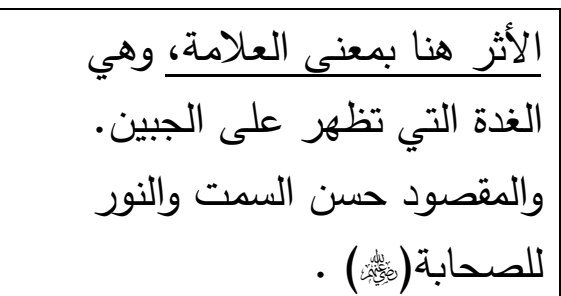 & 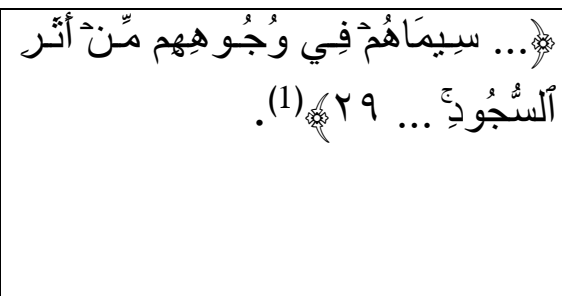 & 8 \\
\hline 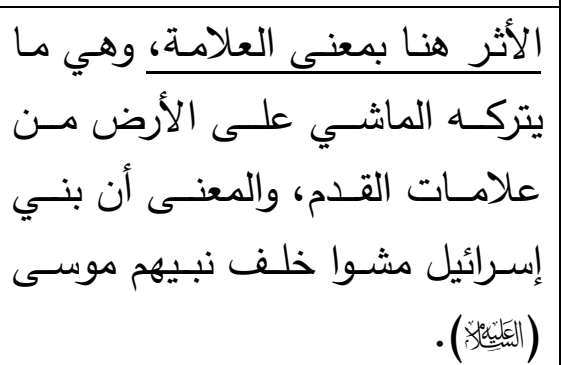 & 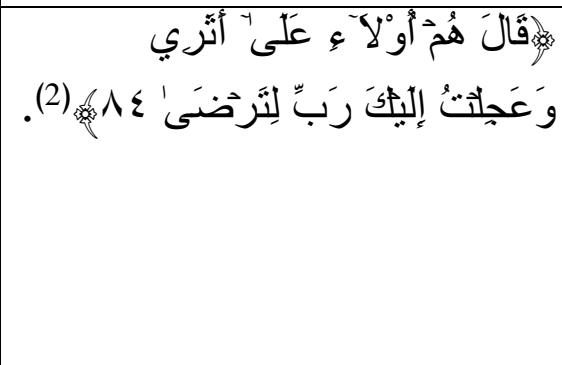 & 9 \\
\hline 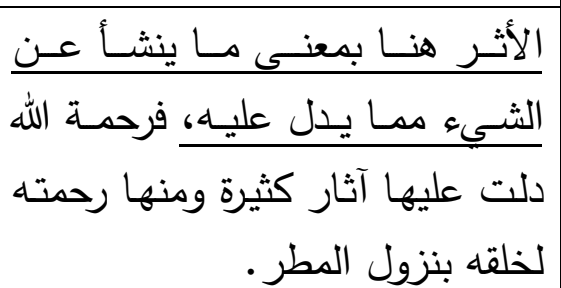 & 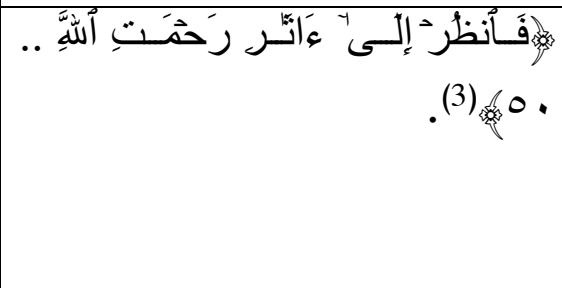 & 10 \\
\hline 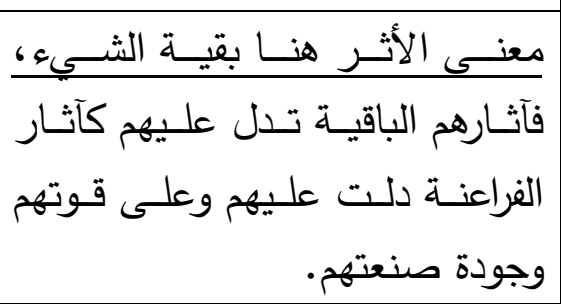 & 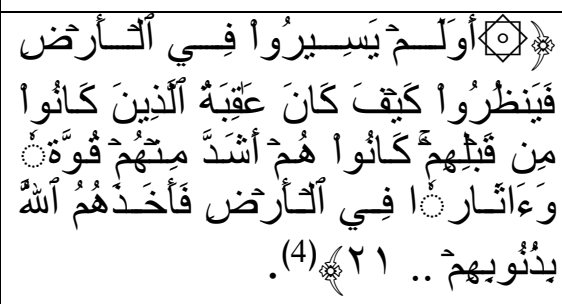 & 11 \\
\hline 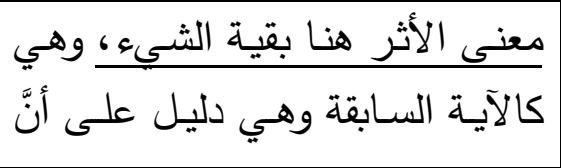 & 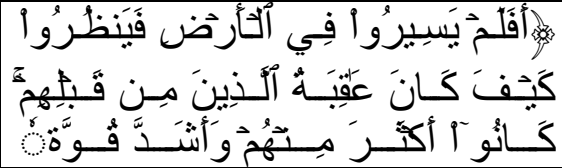 & 12 \\
\hline
\end{tabular}




\begin{tabular}{|c|c|c|}
\hline 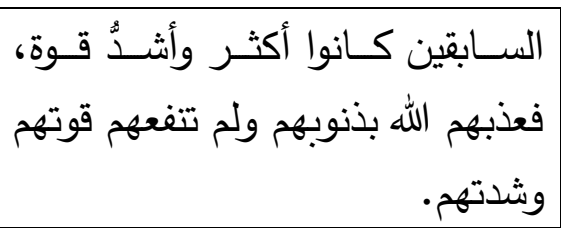 & 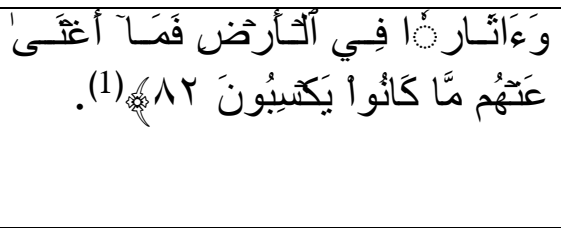 & \\
\hline الأثــر هنـا بمعنــى التفضــيل، أي & 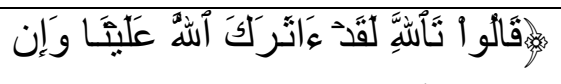 & 13 \\
\hline فضلك الله يا يوسف علينا. & 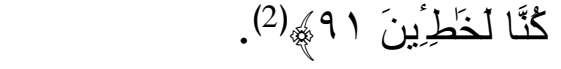 & \\
\hline الأثر هنـا بمعنـى المـأثور والمـروي & 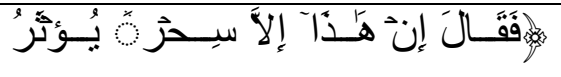 & 14 \\
\hline 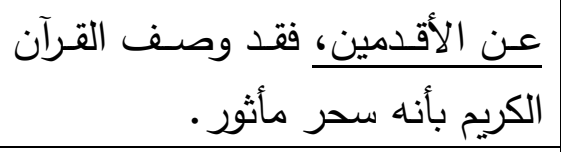 & ) $Y \leq$ & \\
\hline 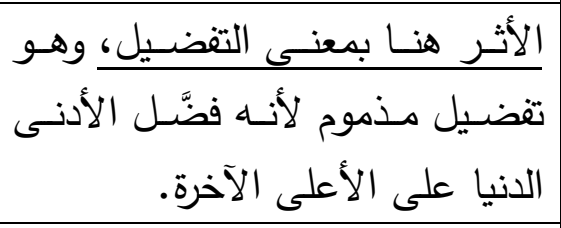 & 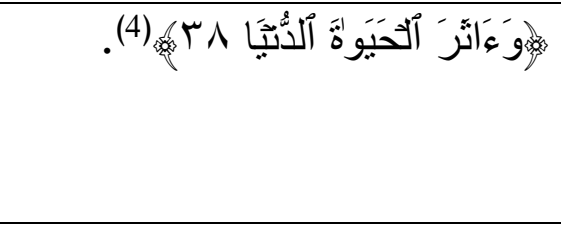 & 15 \\
\hline نفس معنى الأثر في الآية السابقة. & 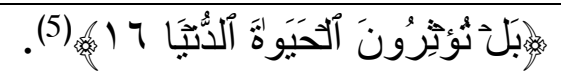 & 16 \\
\hline 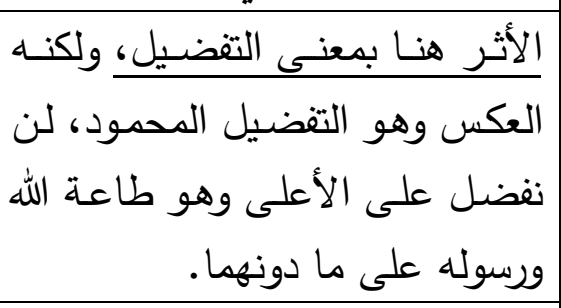 & 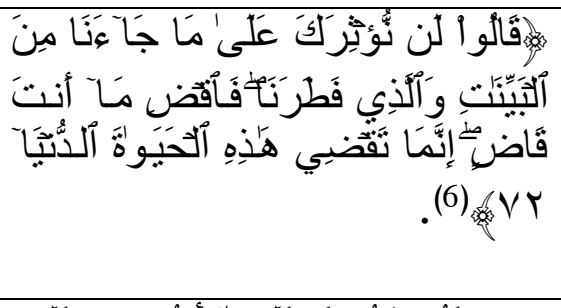 & 17 \\
\hline شئ الأثر هنـا بعنـى الترجيح، ترجيح & 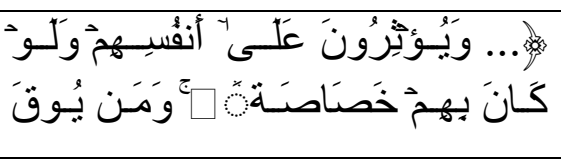 & 18 \\
\hline
\end{tabular}

(1)

(2) يوسف، 91.

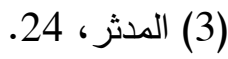

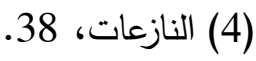

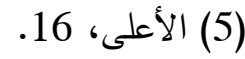

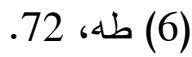




\begin{tabular}{|c|c|c|}
\hline فلرجحَّ الصـحابة من الأنصـار تقدين & 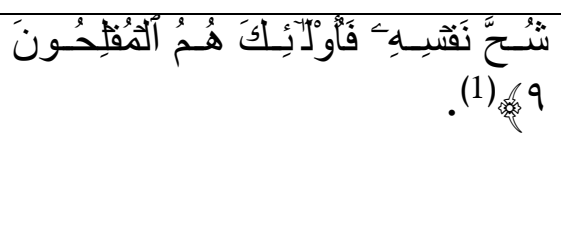 & \\
\hline 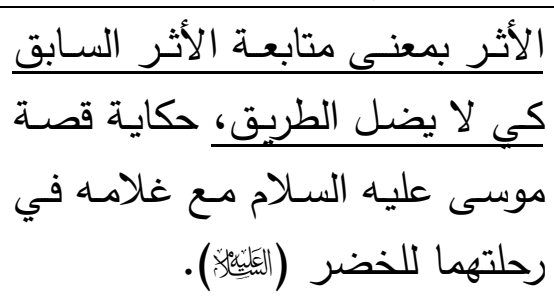 & 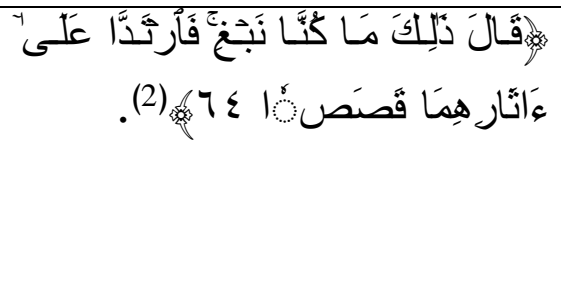 & 19 \\
\hline بقية علم عندكم (4). بقأثر بقية الثي، والمراد & 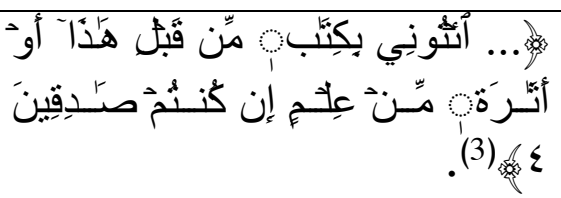 & 20 \\
\hline
\end{tabular}

لقد ورد ذكر الأثر ومشتقاته في القرآن الكريم في 20 آيـة كريمة، سبع مرات للفظ " آثارهم" ومرتين للفظ " أثر" ومرتين للفظ" آثاراً" ثم مرة واحدة للألفاظ التالية: يؤثر - آثر - آثرك- تؤثرون - نؤثرك- أثري -آثارهما - أثارة(5)

\section{الإطب الثاني}

$$
\text { (1) (1) الحشر، } 9 \text { (3) الأحقاف، } 4 .
$$

(4) ينظر : تقسير الجـامع لأحكـام القـرآن، الإمـام القرطبي، 15/15، ط 1، 14، 1418هـ، دار

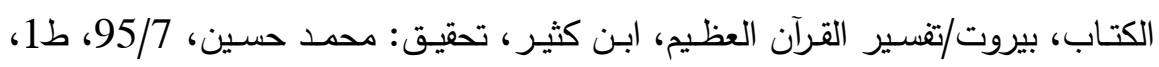

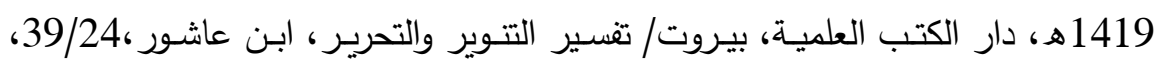

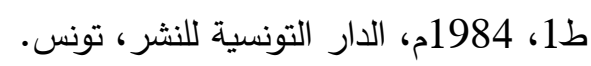

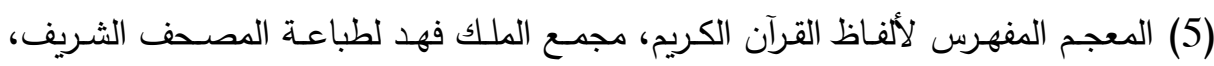

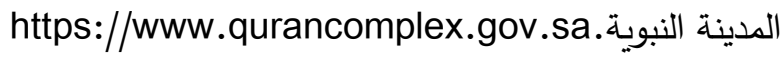




\section{معنى الألثر في المديث الشريف}

مـا ورد في القرآن الكريم من معاني الأثر ، ورد مثله في الحديث الشريف (1) ولنفس معاني الأثر ومن ذلك:

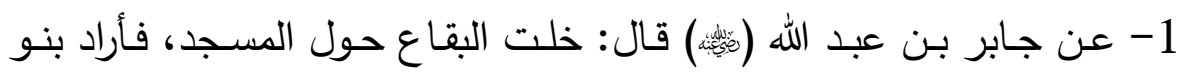

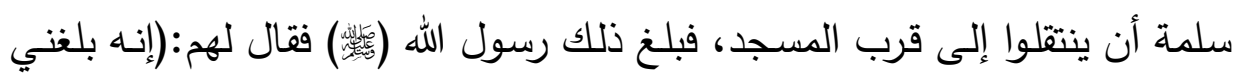
أنكم تريدون أن تتتقلوا قرب المسجد) قالوا: نعم يا رسول الله قد أردنا ذلك. فقال: (يا بني سلمة دياركم تُكتب آثاركم، دياركم تُكتب آثاركم)(2). والمعنى تُكتب تُبن آثار أقدامهم للمشي للصدلاة ثواباً من عند الله.

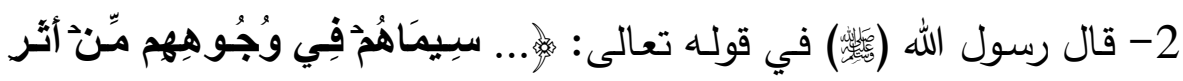

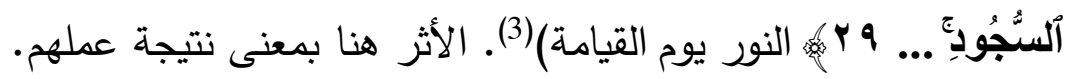

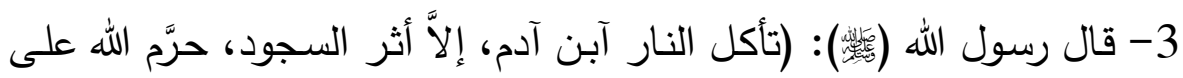
النار أنْ تأكل أثر السجود)(4). الأثر هنا بمعنى بقية الثيء.

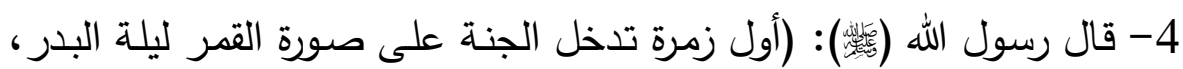

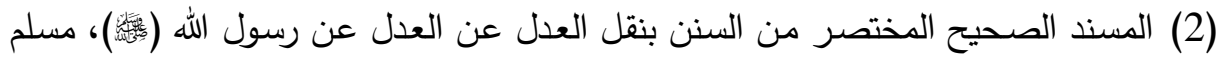

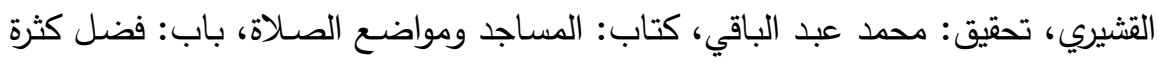
الخطى إلى المسـاجد، حديث رقم: 1074، ط1، 1374هـ ــ دار إحياء الكتب العربيـة،

$$
\text { عيسى البابي الحلبي. }
$$

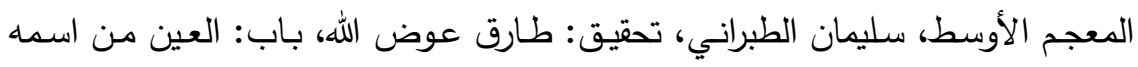

عبد الله، رقم الحديث:4461، إسناده حس، ط1، 1415هـ، دار الحرمين، القاهرة. ـ (432) سنن ابن ماجه، كتاب الزهد ، باب صفة النار رقم الحديث: 4326. 


\section{حولية كلية أصول الدين والدعوة بالمتوفية العدد الثامن والثلاثثرن}

والذين على آثارهم كأحسن كوكب دري في السماء إضـاءة)(1). الأثر بمعنى

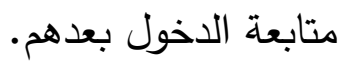

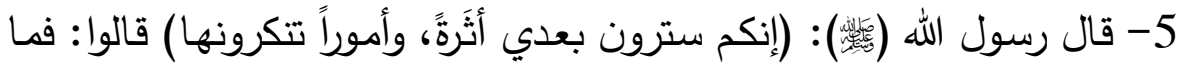

تأمرنا يا رسول الله؟ - اله

قال: (أدَّوا إليهم حقهم، وسلوا الله حقكم)(2) والأثر هنا بمعنى التضضيل والإيثار

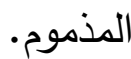

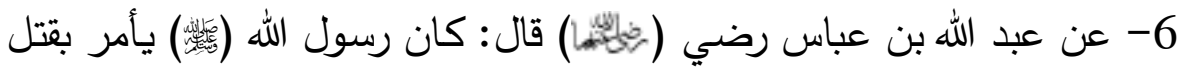

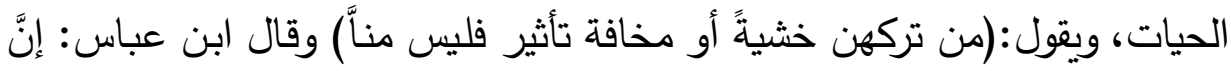

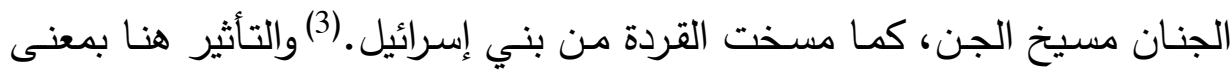

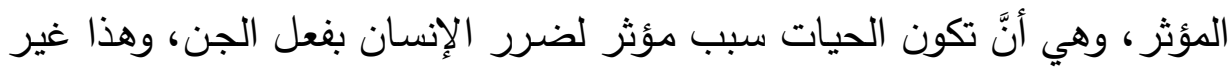

صـحص?

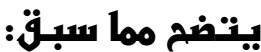

أن معاني الأثر في القرآن الكريم والحديث الثريف هي: العلامهة، والنتيجة، وبقية الثيء، وذكر الثيء، والأمر المأثور عن السابقين المروي عنهم، والأثرة

صحيح مسلم، كتاب: الجنة وصفة نعيمها وأهلها، باب: أول زمرة تدخل الجنة، رقم

الحديث: 2834.

(2) الجامع الصحيح المسند من حديث رسول الله وسننه وأيامه، الإمام البخاري، كتاب: الفتن، الفئ، باب: قول الرسول سترون بعدي، رقم الحديث: 6644، ط1، 1400هـ، الدكتبة السلفية، القاهرة.

(3) حاشية مسند الإمام أحمد بن حنبل، تحقيق: نور الدين سندي، مسانيد أهل البيت، مسند

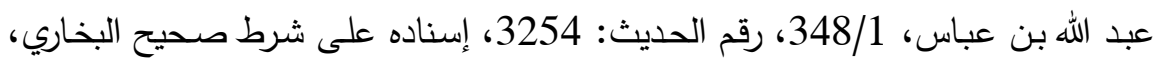
ط1، 1428ه، وزارة الأوقاف والثئون الإسلامية، قطر بـ 
والإيثار تأتي على التفضيل تارة المحمود، وتارة المذموم، وتأتي بمعنى متابعة الأمر السابق والتصسك به، ويأتي الأثر بمعنى المسِّبب للشيء.

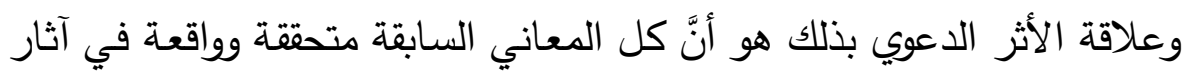

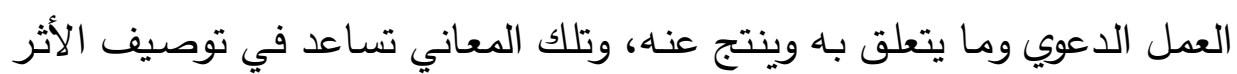
الدعوي، وحمله على المعنى الشرعي المناسب له.

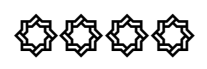




\section{حولية كلية اصول الدين والدعوة بالثنوفية العدد الثامن والثلاثثرن}

\section{الإبمث الثالث}

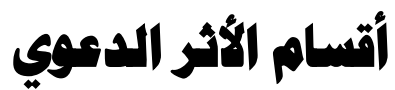

يمكن تقسيم الأثر الدعوي وفق أركان الدعوة الأساسية، فتكون الأقسام خمسة كالتالي: 1- الأثر الدعوي على الدعاة(1) إلى الله تعالى. 2- الأثر الدعوي على المدعوين(2). 3- الأثر الدعوي على موضوع الدعوة الدعان.

4- الأثر الدعوي على وسائل الدعوة وأساليبها(4). 5- الأثر الدعوي على منهج الدعوة إلى الله(5).

(1) تعريــ الداعية هو : "كل مسلم مكلف اشتغل بهداية الناس وبدلالتهج على الله تعالى"

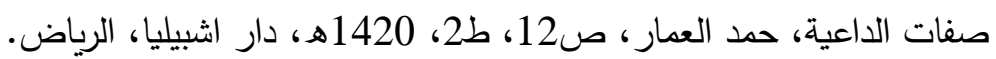

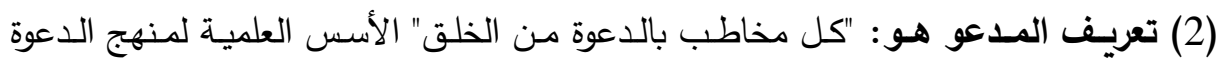

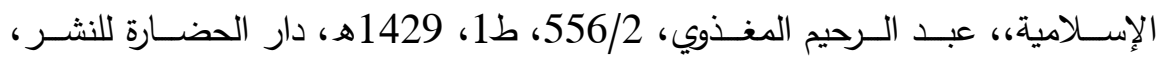

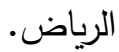

(3) تعريف موضسوع الدعوة هو: "وهو المضمون أو المحتوى الذي يتضمنه خطاب الداعي

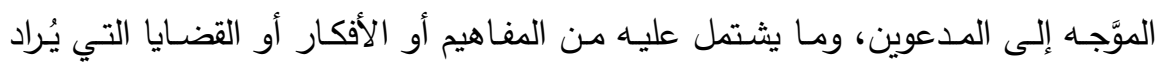

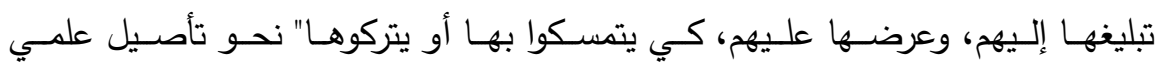

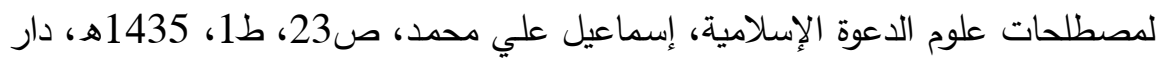
الكلمة للنشر والتوزيع، القاهرة. (4) تعريف وسائل الدعوة هي: "الطرق التي يتوصل بها الداعي إلى تبليخ دعوته" رسالة في

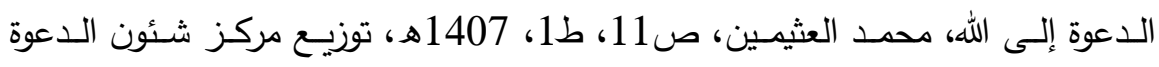
بالجامعة الإسلامية، المدينة النبوية.

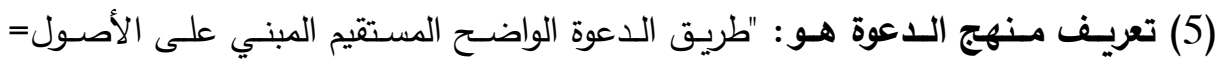
- 335 - 
قبل البدء في بيان الأثر الدعوي لأركان الدعوة الأساسية، أرى ضـرورة بيان

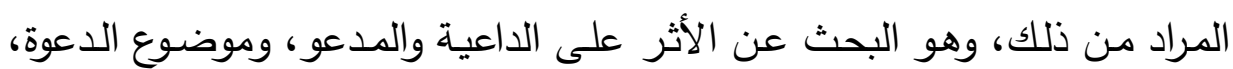
ووسائل الدعوة وأساليبها، والمنهج المتبع، كل ذلك يكون في مجال الدعوة، ولذلك

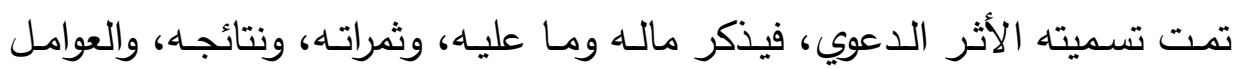

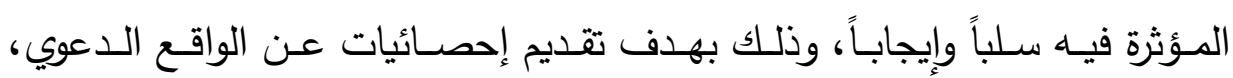
والإجابـة عن سؤال مهم وهو: الدعوة الإسـلامية بأركانها الخمسـة الأساسية أيـن موقعها الآن محلياً، وإقليمياً، ودولياً؟ والإجابة عن السؤال تكون وفق إحصـائيات دقيقة، مدونـة في سجلات ورقيـة والكترونيـة يستطيع المطلـع عليهـا معرفـة واقـع الـدعوة الإسـلامية معرفـة علميـة موثوقة، وليس معرفة قائمة على التقديرات العامة والرؤية الثاملة، أو معرفة متأثرة بردود الأفعال، التي كثيرا لا تبرز الإنجازات الصغيرة الدعويـة، والتي لها دلالات

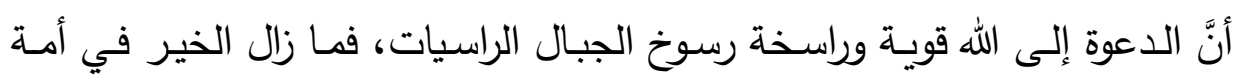

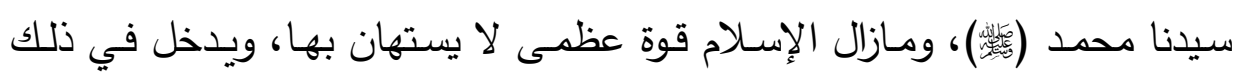

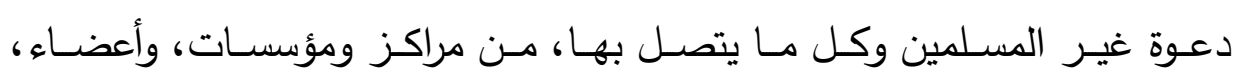
وميزانيات(1).

إنَّ الواقع الدعوي المؤسسي محلياً، وإقليمياً، وعالمياً، إذا كان مبنياً على نظام

=الصحيحة الثابتة من القرآن الكريم والسنة المطهرة وآثار السلف الصسالح، الذي سلكه

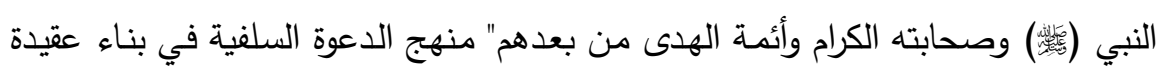

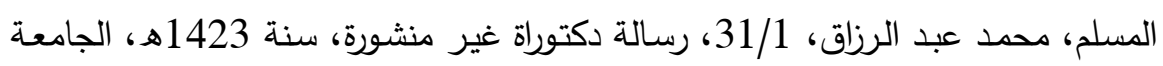
الإسلامية، المدينة النبوية.

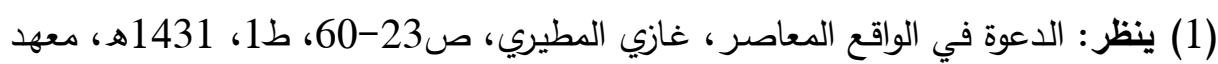
البحوث وإحياء التراث الإسلامي، جامعة أم القرى، مكة المكرمة. 
ولوائح، وتخطيط ودراسـات، ويصدر عنه إحصـائيات وتقارير ، سوف يساعد على إظهار الأثر الدعوي بدقة، فيمكن التطوير والتحديث، ويمكن معالجـة المعوقات وتهري والثغرات، ويمكن منع المؤثرات التي تضر بالدعوة وتفقدها ثمرات المكتسبات التي حصلت عليها. 1 - الأثر الاعوي للاعاة إلى الله تعالى: عندما يلتحق المسلم والمسلمة بركب الدعاة إلى الله، ما هو أثر الدعوة عليه؟

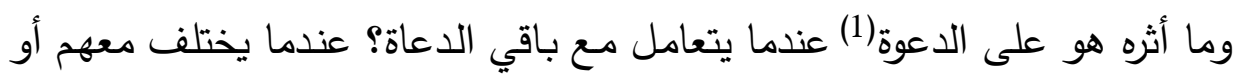

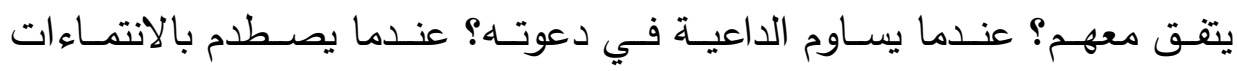
والحزبيات، والجماعات والحركات، ما أثر هذا الواقع الدعوي عليه؟ عندما يدرك بك به

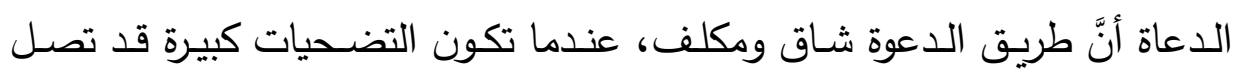

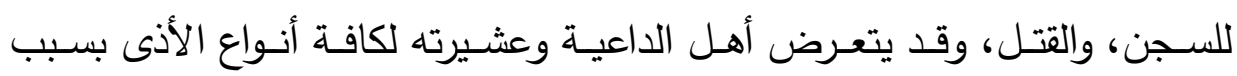

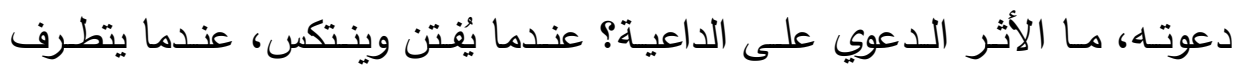
ويتنطع، عندما يتنازل عن الثوابت الجوهرية في الآدين!!

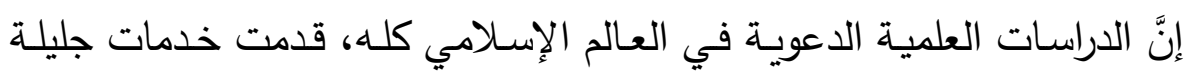
وعظيمة في بيان الأثر الدعوي على الدعاة إلى الله تعالى (2) وكانت نتائجها وفق الإنى إحصائيات ودراسات ميدانية، بُنيت عليها مشاريع وبرامج لتدريب الدعاة وتأهيلهم،

(1) ينظر : الضـغوط النفسية في حياة الداعية، عوض مرضـاح،7-48، ط1، مدار الوطن

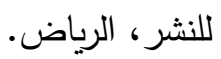

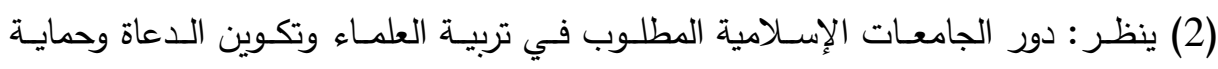

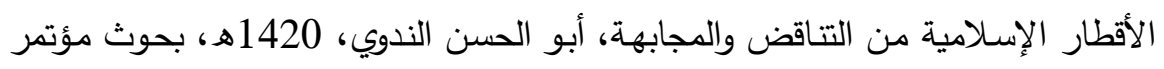

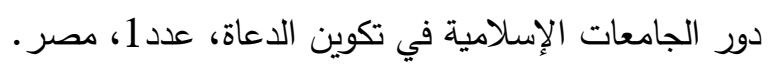
/ http: search.mandumah.com 
وتطـويرهم وتحسين أدائهم الدعوي، ومـا زال الخير والجهـود مستمرة بتوفيق الله وفضله، وجهود المخلصين العاملين في مجال الدعوة. وهذا من الأثر الدعوي الإيجابي على الدعاة، والمرجو تطوير هذا الأثر ليكون شمولياً، وموحداً، ومنهجياً، وممتداً على المستوى المحلي والإقليمي والعالمي. 2- الأثر الدعوي على المدعوين:

جاء في القرآن الكريم والسنة النبويـة الشريفة تصنيف دقيق لأنواع المدعوين،

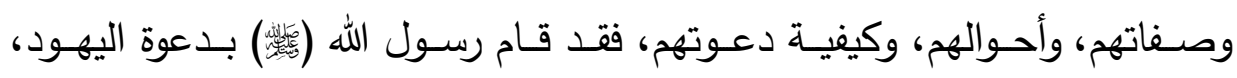

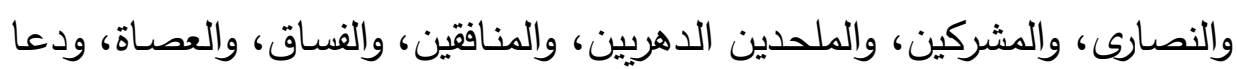

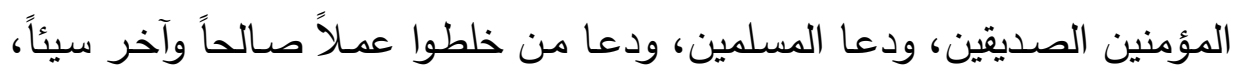
فدعوته (نائَّ) شملت كل أنواع المدعوين، الذين لا يتصور وجود نوع آخر غيرهم وهذا من كمال التشريع الإسلامي وشموله(1). والسؤال هو: ما الأثر الدعوي للدعوة الإسـلامية محلياً وإقليمياً وعالمياً، على ولئ كل أنواع المدعوين السابقين؟ وما التقييم الحقيقي لواقع الدعوة الإسـلامية؟ الذي لـه تأثير كبير جدا على كل أنواع المدعوين في الاستجابة للدعوة أو النفور منها.

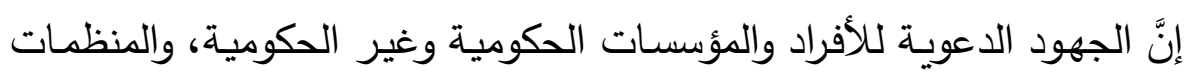
الإسلامية الدولية لا تُكر ، وهي جهود معتبرة، ومؤثرة، وقوية، وكلها ترصد الأثر

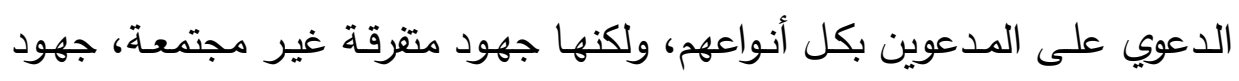
متكررة، جهود تحمل الخير الكثير في محتوياتها، وما يُستفاد منها إلا القليل جداً، وغاية البحث الدعوة إلى جمع هذه الجهود والاستفادة من نتائجها، وتقديم صورة

(1) ينظر : أصناف المدعوين وكيفية دعوتهم، حمود الرحيلي، ص50، ط1، 1414هـ، دار العاصمة، الرياض. 


\section{حولية كلية أصول الدين والدعوة بالمتوفية العدد الثامن والثلاثثرن}

متكاملـة وشاملة عن واقع الأثر الدعوي على المدعوين بكل أنواعهم، لمعرفـة

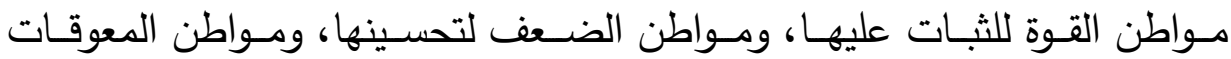

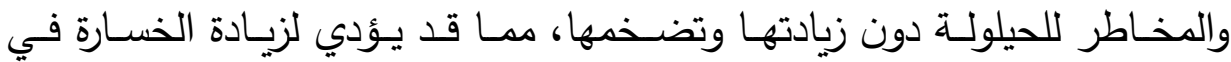
استجابة المدعوين للدعوة (1). 3- الأثر الدعوي على موضوع الدعوة:

إنَّ موضوع الدعوة هو الآّين الإسلامي بعقيدته وشريعته وأخلاقه، وليس جديداً

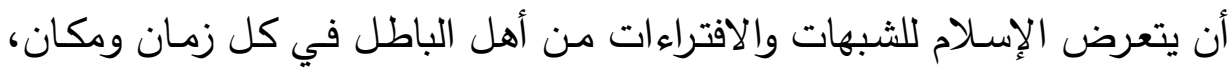

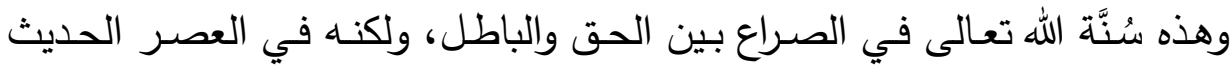

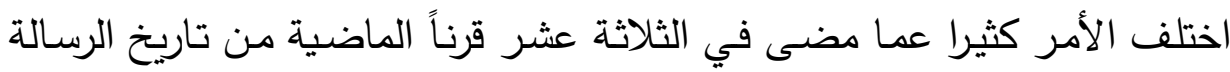
المحدية ففي القرن الحالي ظهرت ثورة الاتصالات، وعصر المعلومات، وانتقال المعرفة بسرعة هائلة لأهل الأرض جميعا، فأي شبهة يتم وصم الإسلام بها تتنشر

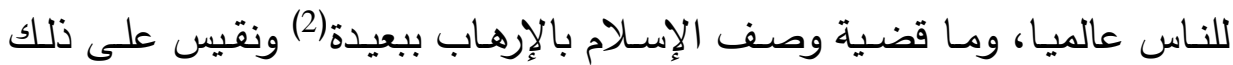

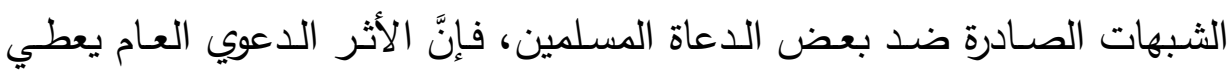

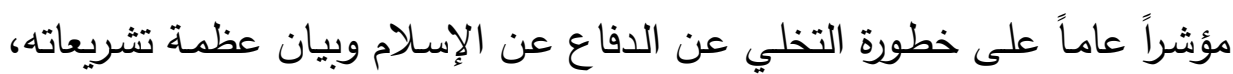
والرد على الثبهات التي شُثار ضده.

وإنَّ من أعظم حسنات عصر الاتصالات والمعلوماتية هو سهوله نثر الإسلام

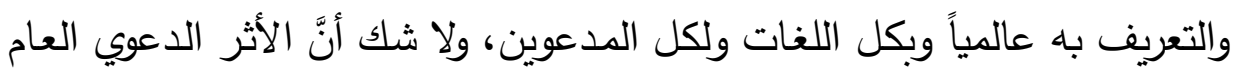

(1) ينظر : تقويم المسيرة الإسـلامية، عـر الأثشقر، ص120، ط1، 1413ه، دار الفتح، باكستان. (2) ينظر : ضعف المؤسسات الدعوية والعلائق بالتطرف والإرهاب، رضوان السيد، ص3 ص-

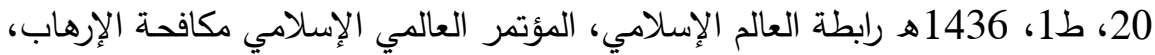

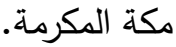


في هذه الحالة يعطي مؤشراً مرتفعاً يبين درجة انتشار الإسلام في العالم ومستوى الانتشار فهل تم رصد الأثر الدعوي الإيجابي والسلبي على موضوع الدعوة الإسـلامية بصورة شمولية، عامة، ومنهجية؟ 4- الأثر الدعوي على وسائل الدعوة وأساليبها: لقد تطورت وسائل الدعوة وأساليبها تطورا هائلا عما كانت عليه سابقاً قبل قرن مـن الزمــان، فمنــذ اكتشــاف الثــبكة المعلوماتيــة العالميـة وثـورة الاتصــالات والمعلومات(1) والجهات المعنية بالدعوة إلى الله تعالى على مستوى الأفراد وعلى التى ونى مستوى المؤسسات والعمل الجماعي تسعى لنقل الإسـلام عبر الوسائل والأساليب الحديثة مثل: الانترنت وما يرتبط به من برامج كالفيس بوك، وتويتر، واليوتيوب،

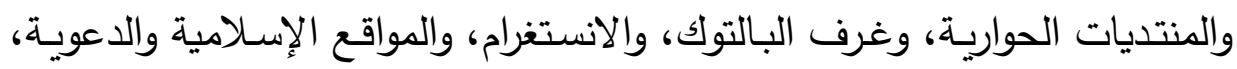
وتقنيات التعليم الدعوي، والتعليم عن بعد، والكتاب الدعوي الالكتروني، والتنوات

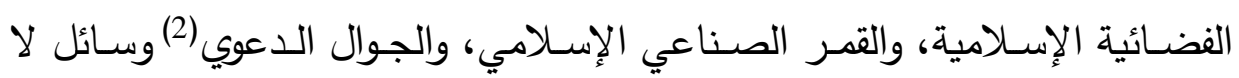

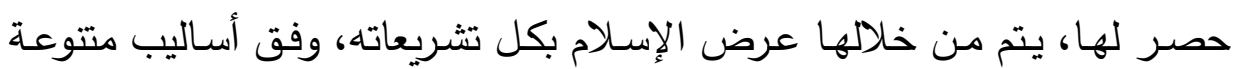
ومتعددة، بين الترغيب والترهيب، وبين التعليم والتدريب، وبين التأصيل والتدليل وبين التطوير والثبات، ويُعَُّ هذا من النعم العظيمة لله تعالى للإسـلام والمسلمين.

(1) ينظر : وسائل الدعوة إلى الله في شبكة المعلومات الدولية، إبراهيم عابد، ص90، رسالة

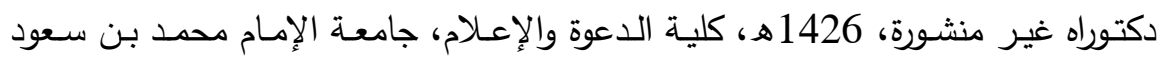
الإسلامية، الرياض.

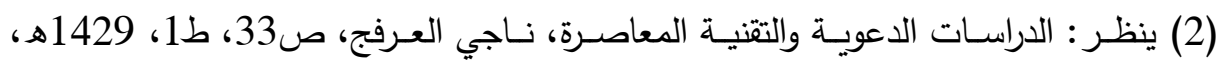

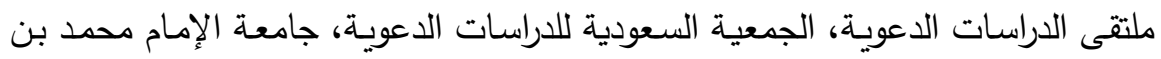
سعود الإسلامية، الرياض. 
إنَّ هـذا التطـور والتقـدم في الوسـائل والأسـاليب أثنره الـدعوي عظـيم يتسـم بالثمول والعموم، شمول لأنه يتضمن الإسلام عقيدة وشريعة وأخلاقاً، وعموم لأنه عمَّ أرجاء المعدورة، فالراعي يرعى غنمه يستطيع عبر جواله الاستفادة من البرامج الدعويـة، وفـي القـرى والبـوادي البعيـدة إذا تيسـر الاتصــال اللاسـلكي وجهـاز الاستقبال، يتم الاستفادة من البرامج الإسلامية والدعوية. هل تم رصد الأثر الدعوي الإيجابي والسلبي على وسـائل الدعوة وأسـاليبها

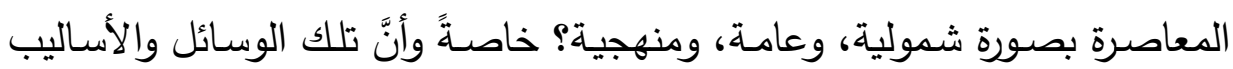
فيهـا الثـيء الكثير مـن الخلـل في نشـر مفهوم اللّدين الإسـلامي الصـحيح، بـل بعضها فيه تشويه للإسلام في نشر التطرف الفكرى، والتشيع، والبدع، والخرافات،

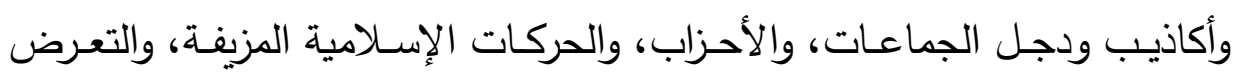
لثوابت الإسلام وأصوله، فهذه الوسائل والأساليب سـلاح ذو حدين، والأثر الدعوي لها قوي ومؤثر على الدعاة والمـدعوين، والحاجـة ماسـة لجهود فرديـة وجماعيـة، ومؤسسـاتية، لدراسـات ميدانيـة ومسـية لاسـتطلاع واقـع الأثر الـدعوي للوسـائل والأساليب بالأرقام والإحصائيات(1). 5- الأثر الاعوي على منهج الدعوة إلى الله:

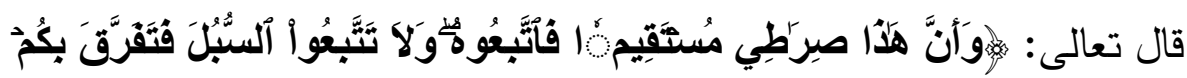

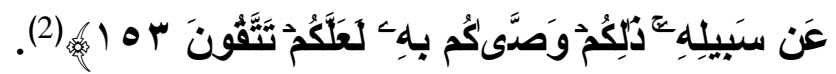

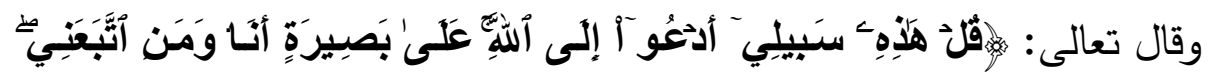
(1) ينظر : معايير الجودة في المواقع الدعوية، نورة الزامل، رسالة ماجستير ميدانية منشورة

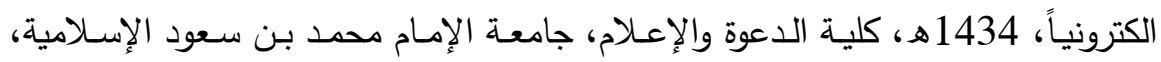

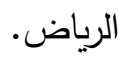
(2) (2) - (2) (الأنعام، 153. 


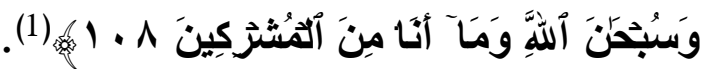

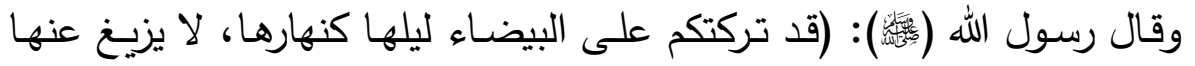

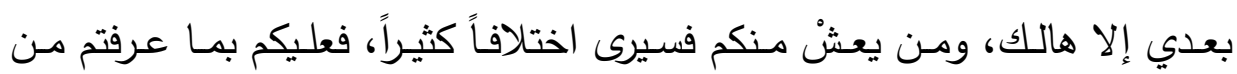

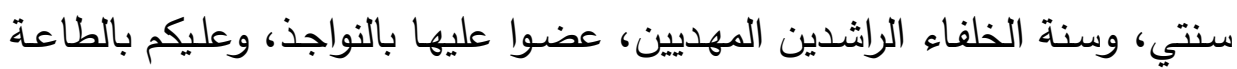
وإن عبداً حبشياً، فإنما المؤمن كالجمل الأنِفِ، حيثما انقيدَ انقاد)(2).

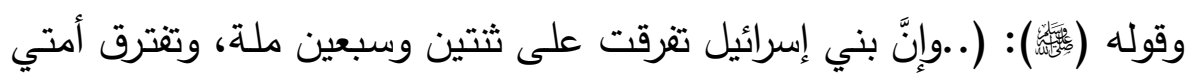

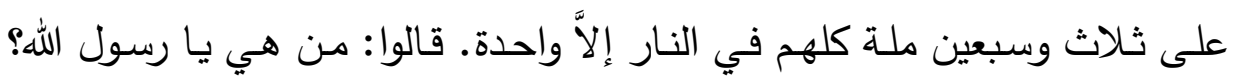

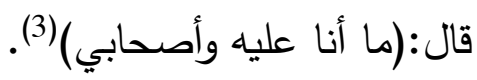

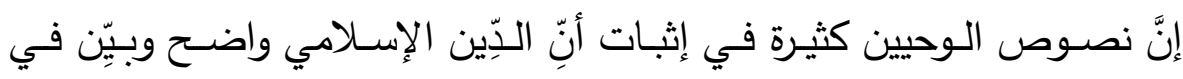

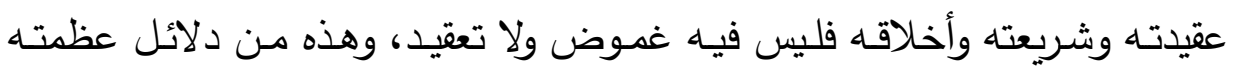

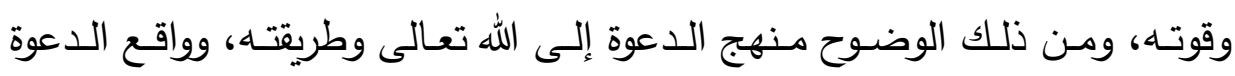

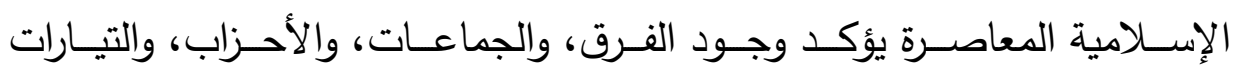

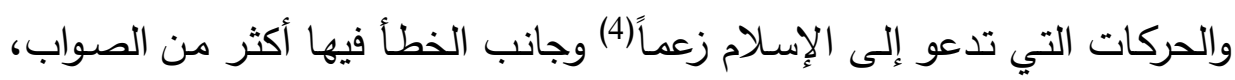

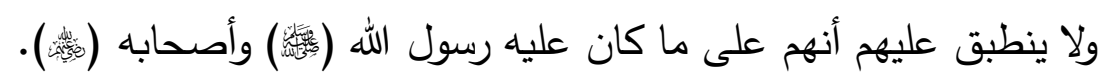
إنَّ الأثر الدعوي على منهج الدعوة بمثل هذا الواقع الإسـلامي (5)ويُضـاف إليه

$$
\text { (1) يوسف، } 108 \text { (1) }
$$

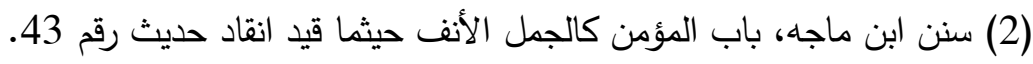

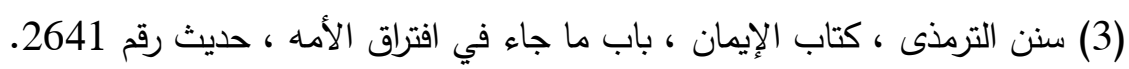

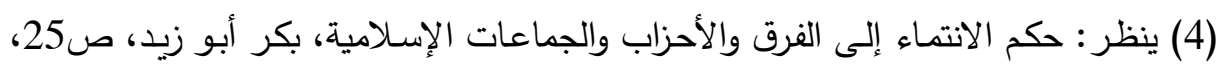

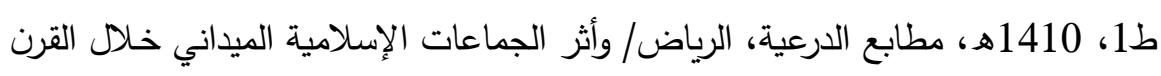
العشرين، محمود عبيدات، ص66، ط1، 1409، 1409ه، مكتبة الرسالة الحديثة، عمَّان.

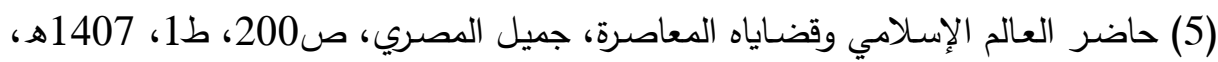
مطابع الجامعة الإسلامية، المدينة المنورة. 
سيطرة الإعلام على ما ينشر ، ويوافق هواها، يجعل قضية معرفـة الأثر الدعوي

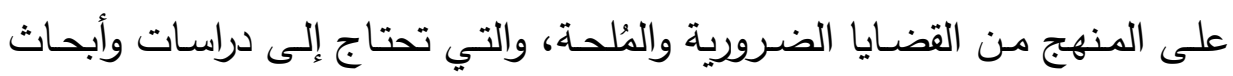

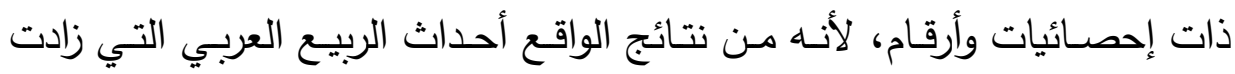

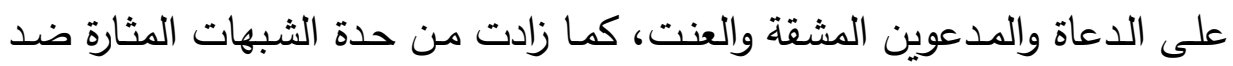

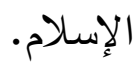

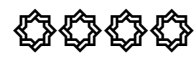




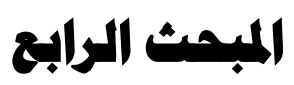 \\ طرق قياس الألثر الدهوي \\ الإنبا الأول \\ توطنة في قياس الأثر الدموي}

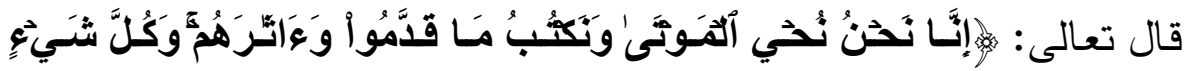

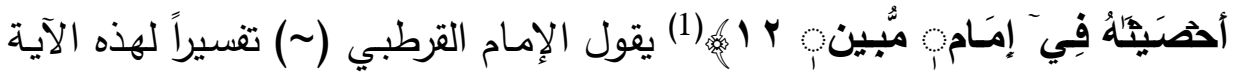

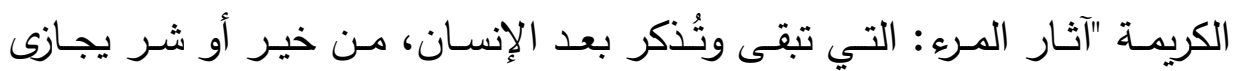
عليها، من أثر حسن؛ كعلم علمهه، أو كتاب صننَّه، أو بناء بناه، من مسجد أو أو

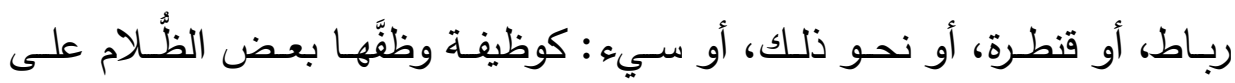
المسلمين، أو سكَّة أحدثها فيها تخسيرهم، أو شيء أحدثه فيه صدُ عن ذكر الله

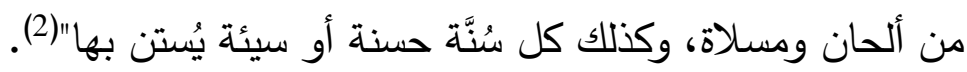
في التفسير السابق بيان أنواع الأثر وهو: أثر حسي وأثر معنوي، وأثر حسن وأثر سيء، وهذا المعنى ينطبق على كل قول وفعل يصدر مـن الإنسان، فمـا يصدر من الإنسـان فهي آثاره الحسنة والسيئة معاً، ولأنَّ الناس في اهتمامـاتهم

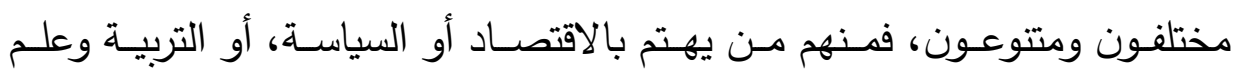
الاجتماع والنفس، وعلم الفيزياء والكيمياء وغيرها، وهذه العلوم والمعارف وضـع لها مختصـوها وأهلهـا طـرق لقيـاس آثارهـا، وأدوات لتحليلهـا وهـي مـا تُعرف بـأدوات القياس من استبانات، ومقابلات، وملاحظات، ومؤشرات كمية ونوعية، ومختبرات 
ومعامل، وتجارب.

فهل الأثر الدعوي يمكن قياسه بنفس تلك الأدوات السابقة؟

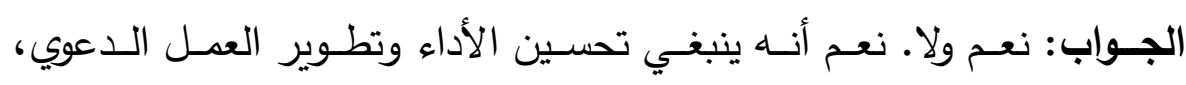

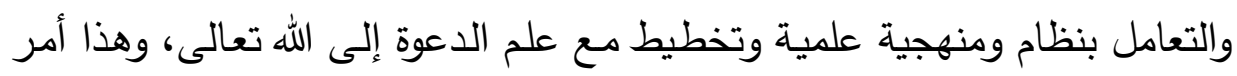

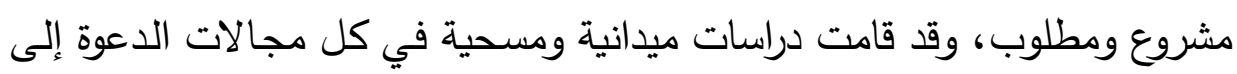

الله.

ولا. لأنَّ الأثر الدعوي مـتبط بالذّين والتثشريع اللذين يختصـان بميزة ليست

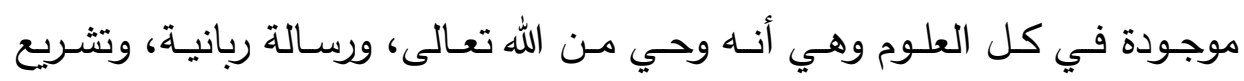

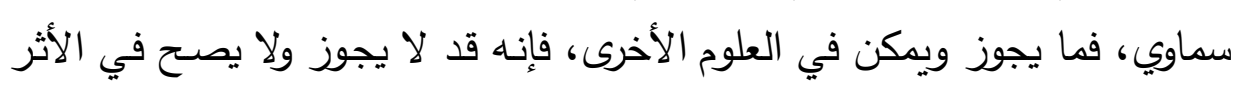

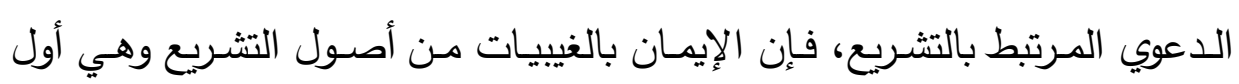

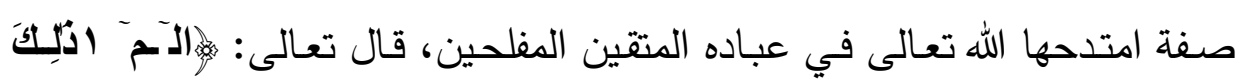

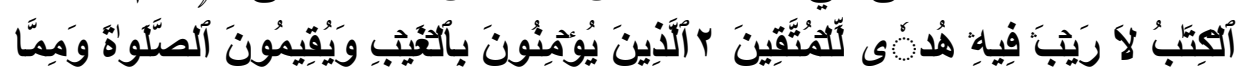

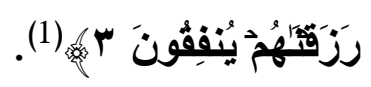

والعلوم الأخرى لا يُنظر فيها إلى هذا الأصل الشرعي العظيم، وهو يُعد عاملاً

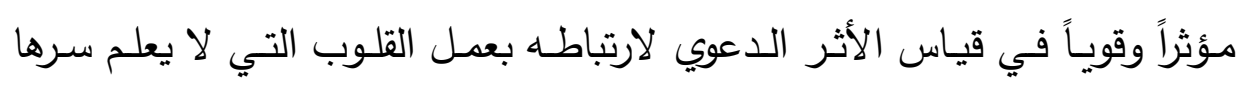
ومكنونها الخفي إلا الذي خلقها الله جل جلاله. 


\section{الإطالب الثاني \\ طرق قياس الأثر الدعوي}

يمكن قياس الأثر بعدة طرق هي:

1- استخدام أدوات القياس المعروفـة مـن استبانات، ومقـابلات، وملاحظـات،

ومؤشرات كميـة ونوعيـة، ومختبرات ومعامـل، وتجـارب، ممـا يُستخدم في العلوم

الأخرى، مـع ضـرورة التنبيـه على الأمـر السـابق وهو ربانيـة هذا الدين وقدسيته، وهذا الأمر ولله الحمد أخذ طريقه في التتفيذ فيوجد دراسات وبحوث دعوية ميدانية ناجحة، تقدم نتائج ذات مصداقية على الأثر الدعوي، والمرجو استمرار هذا النوع من البحوث ودعمها وتثجيعها. 2- النصوص الثرعية التي ورد فيها بيان الأثر الحاصل والمتوقع من القيام بأفعال منصـوص عليها، كآثار الطاعـة والمعصية على مستوى الفرد والجماعـة والدولة والأمـة، وهو ما يُعرف بالسنن الإلهية التي لا تتبدل ولا تتغير ، وهي سنة

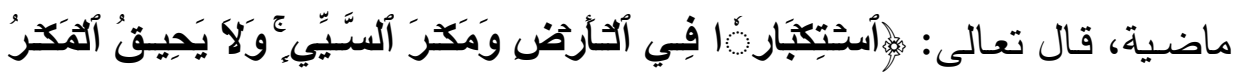

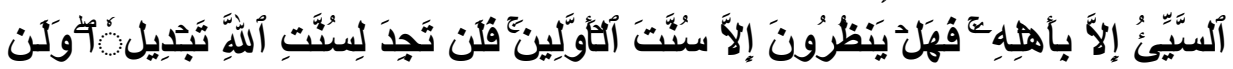

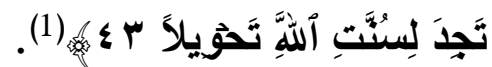

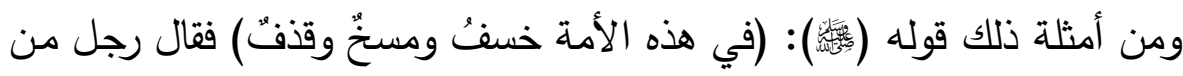
المسلمين: يا رسول الله ومتى ذاك؟ قال: (إذا ظهرت القيان (2) والمعازف وشُربت الخمور)(3) فانتشار المعاصي المنصوص عليها في الحديث من الغناء والمعازف دئ

.43 فاطر (1)

(2) القيان: الأَََّة التي تغنس، والمراد انتشـار الغناء، ينظر شرح الحديث: موقع الموسوعة

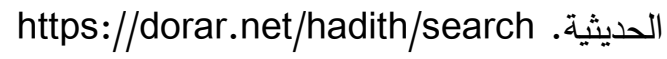

(346) سـن الترمـني،كتاب الفتن ، بـاب قول النبـى بعثت أنـا والسـاعة كهاتين يعنى السبابه 
وشـرب الخمور سيؤدي إلى وقوع أثر المعصية وهو : الخسف والمستخ والقذف، وهذا المعنى كثير جدا في التشريع الإسلامي، وهو ذكر التحذير من ذنوب وكبائر بذكر العقوبات المترتبة على فعلها.

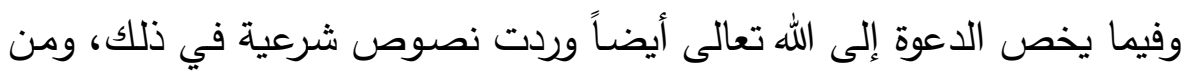

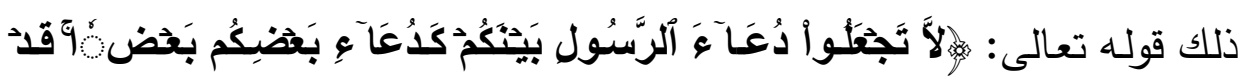

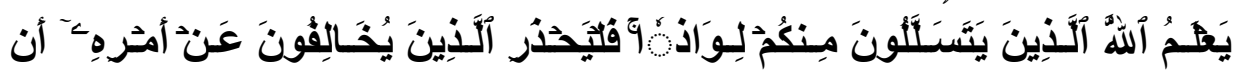

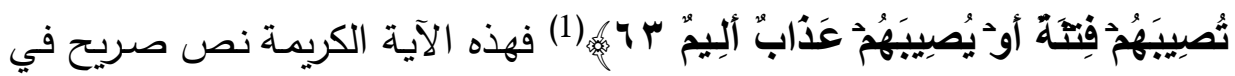

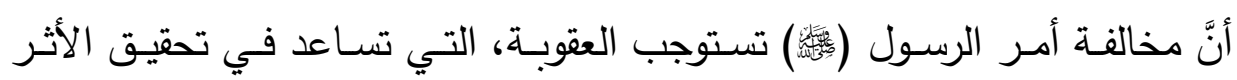

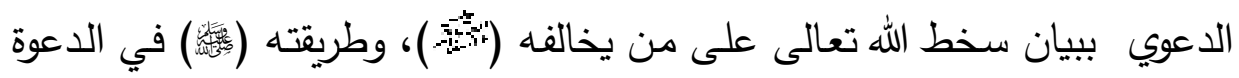

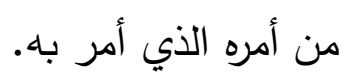
يقول الإمسام القرطبي ( ): "بهذه الآية احتج الفقهاء على أنَّ الأمر للوجوب، لأهرة ووجهها أنَّ الله تبارك وتعالى قد حذَّر من مخالفة أمره، وتوعد بالعقاب عليها ولَأَن

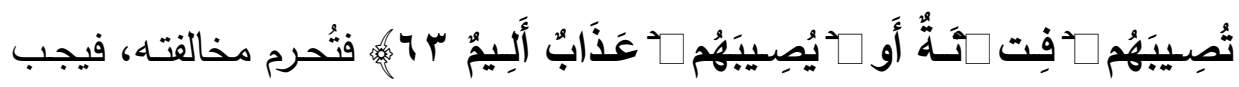
امتثال أمره، والفتتة هنا: القتل قاله ابن عباس، وعطاء : الزلازل والأهوال سلطان جائر يسلط عليهم، وقيل: الطبع على القلوب بثؤم مخالفة الرسول"(2).

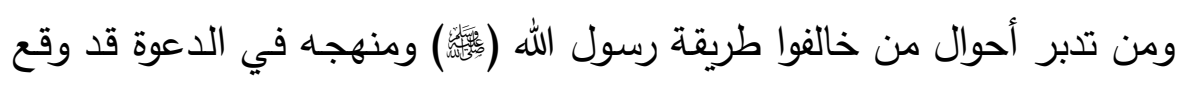
لهم مـن العقوبـة مـا ذكره الإمـام القرطبهي في تقسيره، مـن قتل وسـن وتهـ وتسلط الظالمين عليهُ، والطبع على القلوب، فَعِظَمَ العقوبة لِعِظم الذنب.

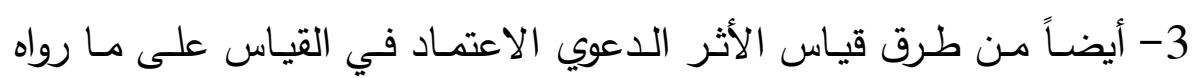

$$
\text { والوسطى رقم الحديث:2212. }
$$
(2) تقسير القرطبي، 323/12، مرجع سابق. 
شهود العيان لأثر حَدّثٍ معين. وهو ما يُعرف بالخبر المتواتر بين الناس. مثل استجابة المدعوين وتأثرهم بعالم معين وداعية مخصوصول وإقبالهم عليه،

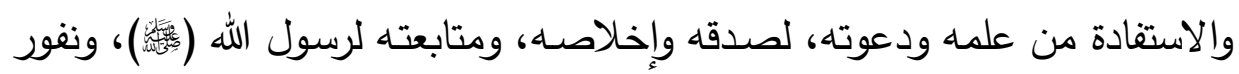
المدعوين وبغضههم لعالم معين وداعية آخر لظهور نفاقهه وكذبه، واتخـاذه الذِّين

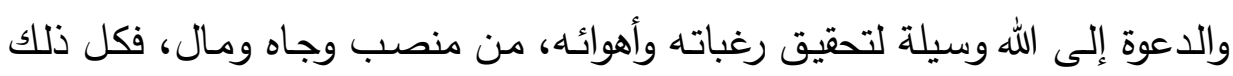
يُعرف بالتواتر وشهود العيان، وهي طريقة لقياس الأثر الدعوي لا يمكن إغفالها وتجاهلها.

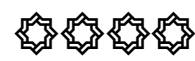




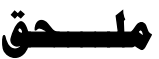

\section{الدراسات والبموث العلمية في موضوع الأثر الدموي}

\begin{tabular}{|c|c|c|c|c|}
\hline 1لناشاشر & نو عها & المؤلف & الأبـحاث العلمبة & م \\
\hline 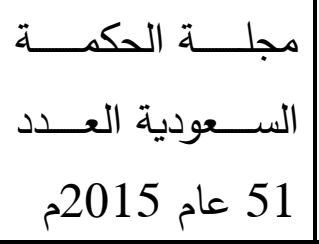 & محكث علمي & 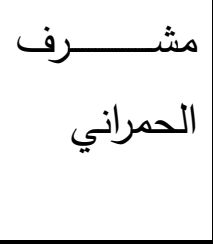 & في الحوارات العلمية وأثرها & 1 \\
\hline دجلـــة جامعـــة أم & محكث علمي & 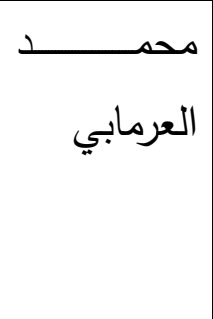 & 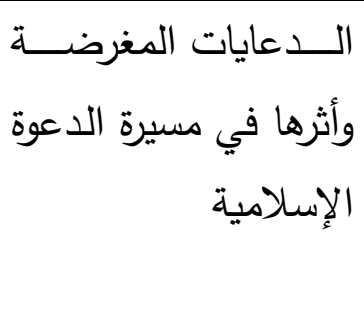 & 2 \\
\hline 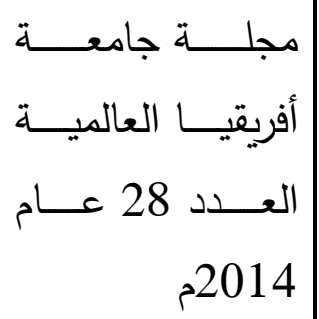 & بحثث علمسي & البكري & العرف وأثره في الدعوة & 3 \\
\hline المـــؤتمر الــدولي & بحث علمي & مصــــــى & 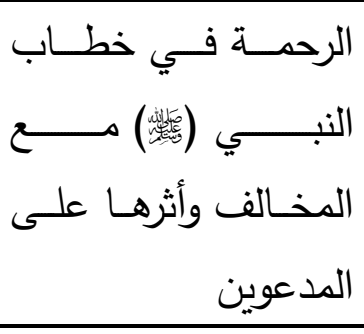 & 4 \\
\hline 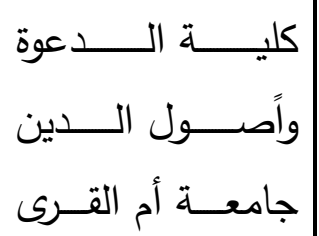 & ماجستير & أروى & 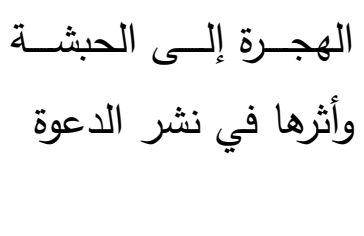 & 5 \\
\hline
\end{tabular}


الأثر الدعوي "مفهومه - أقسامه - طرق قياسه"

\begin{tabular}{|c|c|c|c|c|}
\hline 1431هـ & & & & \\
\hline 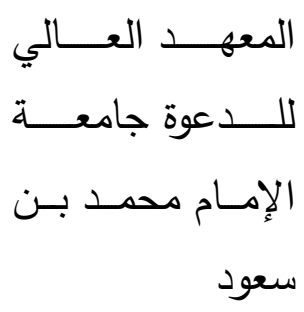 & محكم علمسي & 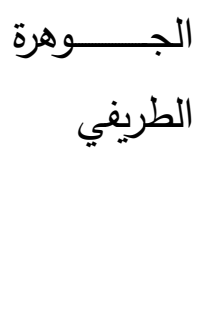 & 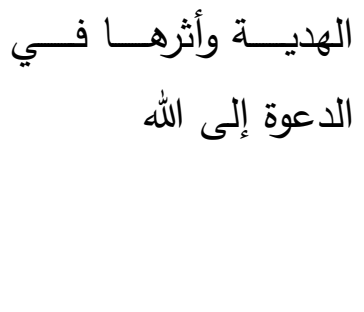 & 6 \\
\hline 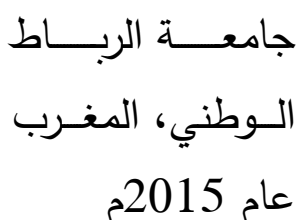 & ماجستير & 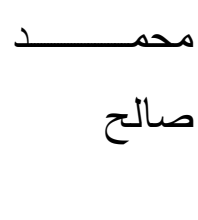 & ثقافة الداعية وأثرها في & 7 \\
\hline
\end{tabular}

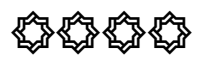




\section{حولية كلية اصول الدين والدعوة بالثنوفية العدد الثامن والثلاثثون}

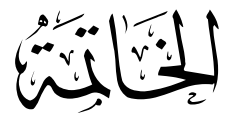

الحمد لله الذي بنعمته وفضله تتم الصالحات، والحمد لله على تيسيره ومعونته

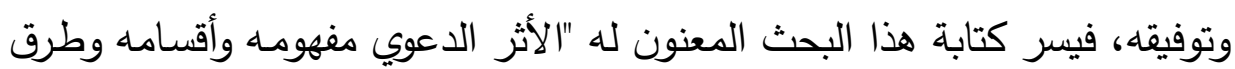

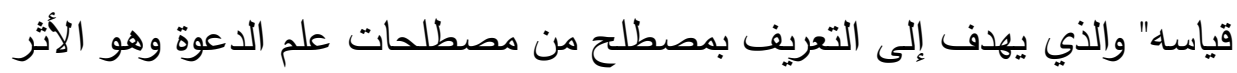

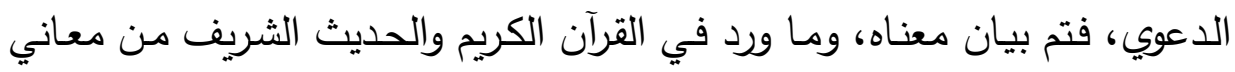

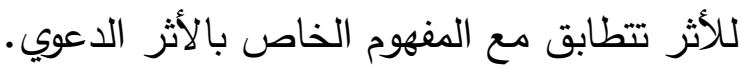

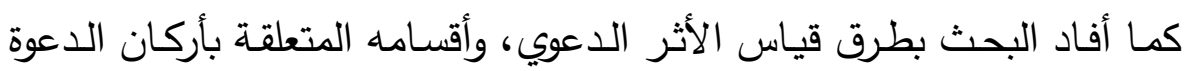

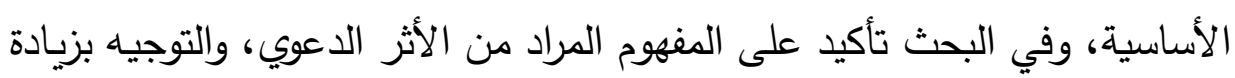

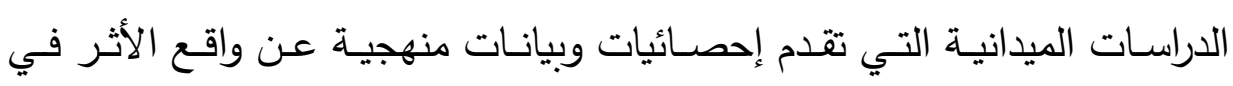

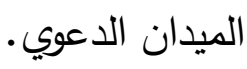

\section{نتنائم البحث البه}

انتهى البحث إلى نتائج من أهمها: 1- وضـع تعريف اجرائي لمصطلح الأثر الدعوي وهو : (مخرجـات العـل

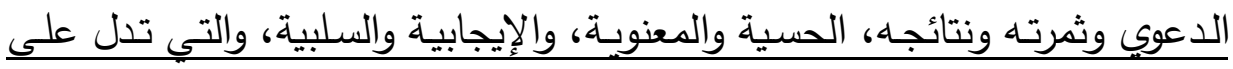
مستوى الدعوة الكقدمة ونوعيتها). 2- التفصيل في شرح مغردات تعريف الأثر الدعوي. 3- التعريف اللغوي والاصطلاحي للفظ الأثر. 4- بيان معاني الأثر في القرآن الكريم والحديث الثريف.

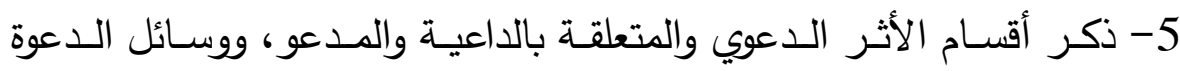
وأساليبها، وموضوع الدعوة ومنهجها.

6- التوجيه إلى أنواع الأثر الدعوي وأنها حسية ومعنوية، وإيجابية وسلبية.

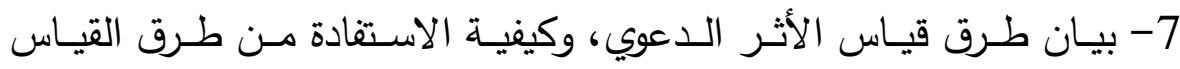


العالمية، وتوظيفها في خدمة الأثر الدعوي وقياسه.

\section{التوصيات}

1- توصسي الباحثة بمزيد من إجراء الدراسـات والبحوث الميدانية على الأثر

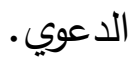
2- هذا البحث مقترح تطويري في علم الدعوة، فهو يدعو إلى استخدام مبادئ الجودة ومعـايير التميز ومؤشـرات الأداء المعروفـة عالميـا، والتي تستخدم لتقيـيم المؤسسـات والمنظمـات، لا استخدامها وتطبيقها في المؤسسـات الدعويـة والمراكز والمنظمات الإسلامية.

3- التوصية بعمل سجل الكتروني يجمع كل الآثار الدعويـة النظريـة والميدانيـة التي تم ذكرها في البحوث والرسائل العلمية. 4- يدخل في مفهوم الأثر الدعوي، الآثار التاريخية الدعويـة، فتوصي الباحثة بالعناية بهذا النوع من الآثار لتوثيق التاريخ الدعوي.

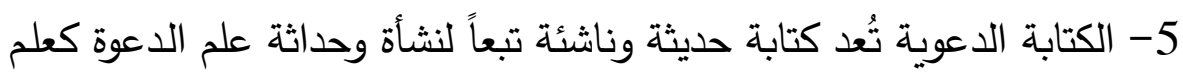
مستقل منبثقِ عن العلوم الشرعية الأخرى، فتوصي الباحثة بالعناية بتوثيق تطور الكتابة الدعوية كأثر من الآثار الدعويـة.

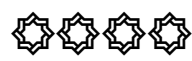




\section{حولية كلية اصول الدين والدعرة بالثنوفية العدد الثامن والثلاثثرن}

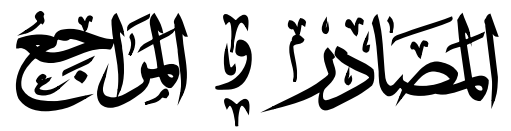

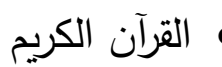

• أثر الجماعـات الإسـلامية الميداني خـلال القرن العشرين، محمود عبيدات، ط1، 1409هـ، مكتبة الرسالة الحديثة، عمَّان.

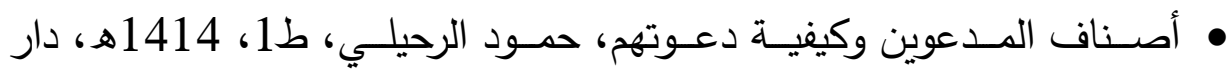

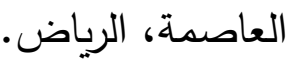
• الأسس العلمية لمنهج الدعوة الإسلامية، عبد الرحيم المغذوي، ط1، 1429هـ، الرياض دار الحضارة للنشر، الرياض.

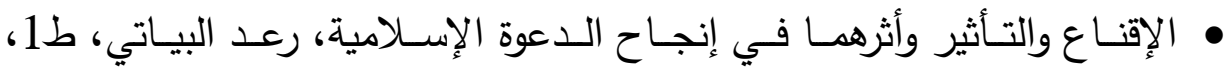

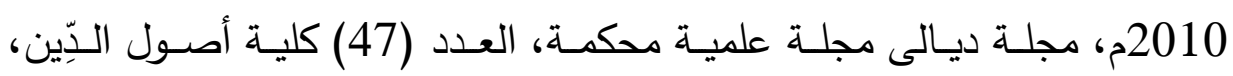

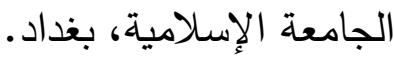

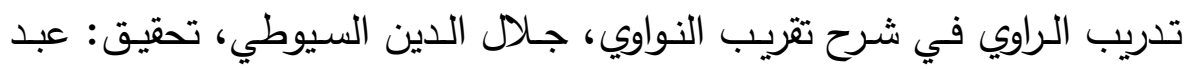
الوهاب عبد اللطيف (د. ط. ت) مكتبة الرياض الحديثة، الرياض.

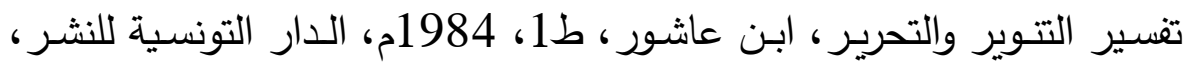
تونس. تقنسير الجامع لأحكام القرآن، الإمام القرطبي، ط 1، 1418ه، دار الكتاب،

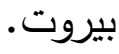
ت تفسير القرآن العظيم، ابن كثير ، تحقيق: محمد حسين، ط1، 1419هـ، دار

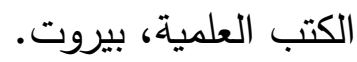
• تقويم المسيرة الإسلامية، عمر الأشقر، ط1، 1413هـ، دار الفتح، باكستان.

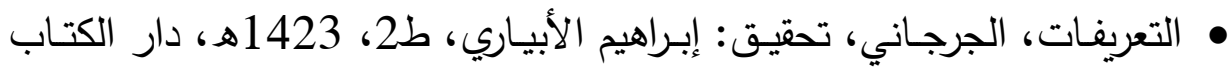




$$
\text { العربي، بيروت. }
$$

•الجامع الصحيح المسند من حديث رسول الله وسننه وأيامـه، الإمـام البخاري، ط1، 1400هـ، المكتبة السلفية، القاهرة. حاشية مسند الإمـام أحمد بن حنبل، تحقيق: نور الدين سندي، مسانيد أهل الهل

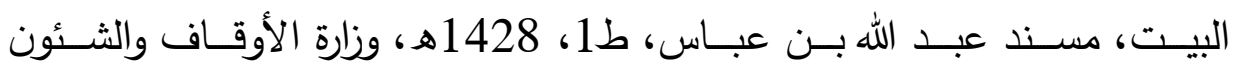

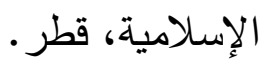
• حاضـر العالم الإسـامي وقضـاياه المعاصرة، جميل المصري، ط1، 1407هـ، مطابع الجامعة الإسلامية، المدينة المنورة. حكم الانتمـاء إلى الفرق والأحزاب والجماعات الإسـلامية، بكر أبو زيد، ط1، 1410هـ، مطابع الدرعية، الرياض. • خصائص الدعوة الإسـلامية، محمد أمين حسين، ط1، 1409هـ، دار البشائر الإسلامية، بيروت.

دور الجامعـات الإسـلامية المطلوب في تربيـة العلمـاء وتكوين الدعاة وحمايـة الأقطار الإسلامية من التتاقض والمجابهة، أبو الحسن الندوي، 1420هـ، بحوث مؤتمر دور الجامعات الإسـلامية في تكوين الدعاة، عدد1، مصر http: search.mandumah.com الدراسـات الدعويـة والتقنيـة المعاصـرة، نـاجي العـرفج، ط1، 1429هـ، ملتقىى الدراسات الدعويـة، الجمعية السعودية للدراسات الدعويـة، جامعة الإمام محمد بن سعود الإسلامية، الرياض. •الدعوة في الواقع المعاصر ، غـازي المطيري، ط1، 1431هـ، معهد البحوث وإحياء التراث الإسلامي، جامعة أم القرى، مكة المكرمة. 


\section{حولية كلية اصول الدين والدعوة بالثنوفية العدد الثامن والثلاثثون}

رسالة في الدعوة إلى الله، محمد العثيمين، ط1، 1407هـ، توزيع مركز شئون

الاعوة بالجامعة الإسلامية، المدينة النبوية.

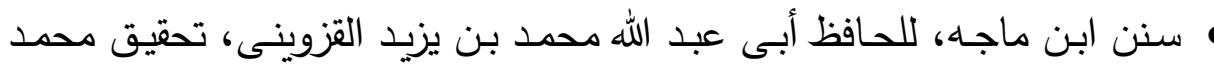

فؤاد عبد الباقى، دار إحياء الكتب العربية.

سنن الترمذي، محمد بن عيسى بن سورة بن موسى بن الضحاك، الترمذى،

ابو عيسى، تحقيق أحمد محمد شاكر .

صفات الداعية، حمد العمار ، ط2، 1420هـ، دار اشبيليا، الرياض.

• ضـف المؤسسات الدعويـة والعلائق بالتطرف والإرهاب، رضوان السيد، ط1، 1436هـ رابطـة العـالم الإسـلامي، المؤتمر العـالمي الإسـلامي مكافحـة الإرهـاب،

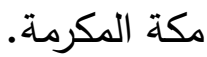

الضغوط النفسية في حياة الداعية، عوض مرضـاح، ط1، مدار الوطن للنشر ،

الرياض.

• قواعد أساسية في البحث العلمي، د. سعيد الصيني، ط1، 1415هـ، مؤسسـة

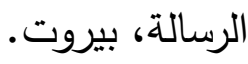

كثـاف اصـطلاحات الفنـون، محمـد التهانوي، (د. ط) 1413هـ، دار الكتب العلمية، بيروت.

لسان العرب، جمال الدين محمد بن منظور ، (د. ط) دار صادر ، بيروت. مركز أصول العالمي للمحتوى الدعوي. مhtps://osoulcenter.com معـايير الجـودة في المواقـع الدعويـة، نـورة الزامـل، رسـالة ماجستير ميدانيـة

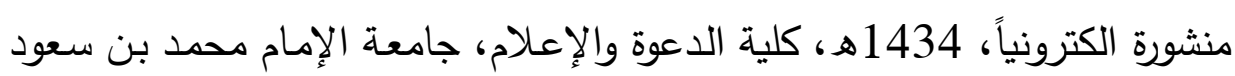
الإسلامية، الرياض. منهج الدعوة السلفية في بناء عقيدة المسلم، محمد عبد الرزاق، رسالة دكتوراة 
غير منشورة، سنة 1423هـ، الجامعة الإسلامية، المدينة النبوية. المعجم الوسيط، مصـطفى إبـراهيم وآخـرون، (د. ط. ت) المكتبـة الإسـلامية، تركيا.

المعجم الأوسط، سليمان الطبراني، تحقيق: طارق عوض الله، ط1، 1415هـ، دار الحرمين، القاهرة. - مان. المعجم المفهرس لألفاظ القرآن الكريم، مجمـع الملك فهد لطباعـة المصـحف https://www.qurancomplex.gov.sa.الشريف، المدينة النبوية •المسـند الصــيح المختصـر مـن السـنن بنقـل العـدل عـن العـدل عـن رسـول

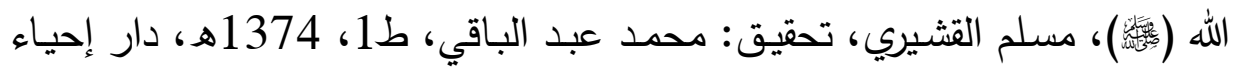
الكتب العربية، عيسى البابي الحلبي. • المفردات في غريب القرآن، الراغب الأصفهاني، تحقيق: محمد كيلاني، ط1 (د. ت) دار المعرفة، بيروت.

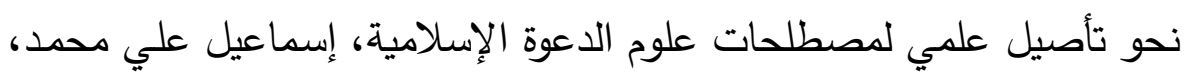
ط1، 1435هـ، دار الكلمة للنشر والتوزيع، القاهرة.

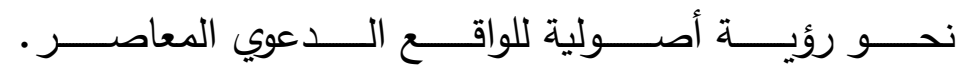
https://www.alukah.net/sharia/0/5830

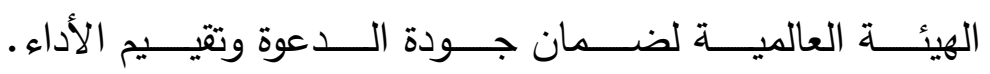
/https://ar.wikipedia.org/wiki وسائل الدعوة إلى الله في شبكة المعلومات الدولية، إبراهيم عابد، رسالة دكتوراه غير منشورة، 1426هـ، كليـة الدعوة والإعـلام، جامعـة الإمـام محمد بـن سـود

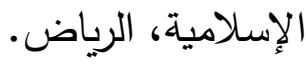

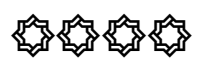




\section{حولية كلية اصول الدين والدعوة بالمنوفية العدد الثامن والثلاثثرن}

فهرس الموضوعات

\begin{tabular}{|c|c|c|}
\hline 1الصفحة & الموضوع & م \\
\hline 311 & ملخص البحث عربي & 1 \\
\hline 313 & ملخص البحث إنجليزي & 2 \\
\hline 324 & مقدمة البحث والتمهيد وخطة البحث & 3 \\
\hline 319 & المبحث الأول: التعريف اللغوي والاصطلاحي للأثر الدعوي & 4 \\
\hline 319 & المطلب الأول: التعريف اللغوي لمفردة " الأثر" & 5 \\
\hline 321 & المطلب الثاني: التعريف الاصطلاحي لمفردة " الأثر" & 6 \\
\hline 322 & التعريف المطلب الثالث: التعريف الاصطلاحي للأثر الدعوي وشرح & 7 \\
\hline 327 & المبحث الثاني: معاني الأثر في القرآن الكريم والحديث & 8 \\
\hline 327 & المطلب الأول: معني الأثر في القرآن الكريم & 9 \\
\hline 332 & المطلب الثاني: معنى الأثر في الحديث الثريف & 10 \\
\hline 335 & المبحث الثالث: أقسام الأثر الدعوي & 11 \\
\hline 337 & 1- الأثر الدعوي على الدعاة & 12 \\
\hline 338 & 2- الأثر الدعوي على المدعوين & 13 \\
\hline
\end{tabular}


الأثر الدعوي "مفهومه - أقسامه - طرق قياسه"

\begin{tabular}{|c|c|c|}
\hline 339 & 3- الأثر الدعوي على موضوع الدعوة & 14 \\
\hline 340 & 4- الأثر الدعوي على وسائل الدعوة وأساليبها & 15 \\
\hline 341 & 5- الأثر الدعوي على منهج الدعوة & 16 \\
\hline 344 & المبحث الرابع: طرق قياس الأثر الدعوي & 17 \\
\hline 344 & المطلب الأول: توطنئة في قياس الأثر الدعوي & 18 \\
\hline 346 & المطلب الثاني: طرق قياس الأثر الدعوي & 19 \\
\hline 349 & ملحق الدراسات والبحوث العلمية في موضوع الأثر الدعوي & 20 \\
\hline 351 & خاتمة البحث & 21 \\
\hline 351 & نتائج البحث وتوصياته & 22 \\
\hline 353 & فهرس المصادر والمراجع & 23 \\
\hline 357 & فهرس موضوعات البحث & 24 \\
\hline
\end{tabular}
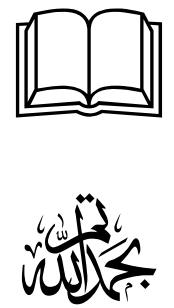